\title{
THE EXCRETION OF AMMONIA AND TITRATABLE ACID IN NEPHRITIS
}

\author{
BY D. D. VAN SLYKE, G. C. LINDER, ALMA HILLER, L. LEITER, AND \\ J. F. McINTOSH
}

(From the Hospital of the Rockefeller Institute for Medical Research)

(Received for publication December 28, 1925)

As the result of past metabolic studies, especially those of Henderson and Palmer (12) it is known that the non-volatile acids produced in excess of fixed base by human metabolism are excreted in the urine in two forms, viz., as free acids, and as ammonium salts.

Since the kidney is unable to form urine with a $\mathrm{pH}$ much lower than 5.0 , it can excrete, in significant amounts, free acids of only the weak buffer type. In this class fall acid phosphates and the various organic acids. It appears, however, that free acid excretion may assist also in elimination of strong acids, which can react with buffer salts (e.g., $\mathrm{HCl}+\mathrm{Na}_{2} \mathrm{HPO}_{4}=\mathrm{H}\left(\mathrm{NaHPO}_{4}\right)+\mathrm{NaCl}$ ), the free buffer acid being excreted in place of the strong acid. Thus Marriott and Howland (19) found that $\mathrm{HCl}$ ingestion increased the output of free buffer acids.

Ammonia serves to neutralize either weak or strong acids. Consequently both ingestion of $\mathrm{HCl}$, (either as such, or as $\mathrm{NH}_{4} \mathrm{Cl}$ or $\mathrm{CaCl}_{2}$ ) and diabetic ketosis (producing weak beta-hydroxybutyric acid) cause increase in ammonia excretion. In fact both the above conditions increase both ammonia and free buffer acid output, without greatly altering the $\mathrm{NH}_{3}$ /acid ratio (Marriott and Howland (19), Fitz and Van Slyke (4)). Peculiarly, however, ingestion of acid phosphate was found by Marriott and Howland to increase only the output of titratable acid, without any effect whatever on the ammonia output.

Since the nature of the acid eliminated, and presumably other unknown factors, can influence the proportions excreted as ammonium salts and titratable free buffer acids respectively, it is not surprising 
that, as shown by Henderson and Palmer, and by our data, wide fluctuations occur in the $\mathrm{NH}_{3}$ /acid ratio even in the same normal individual. To take an extreme case, when a vegetarian diet produces an alkaline urine the $\mathrm{NH}_{3}$ /acid ratio may approach infinity, because the acid factor in the denominator approaches zero, while the ammonia in the numerator, although greatly reduced, is still measurable.

Nevertheless the ammonia in a series of urines from an individual with a normal excretory mechanism ordinarily averages from 1 to 2.5 times the free acid; and this ratio is maintained over great ranges of total $\mathrm{NH}_{3}+$ acid output, e.g., from a low normal $300 \mathrm{cc}$. of $0.1 \mathrm{~N} \mathrm{NH}_{3}$ + acid per 24 hours to the 4,000 or $5,000 \mathrm{cc}$. that may be excreted in diabetic acidosis. There is apparently some tendency towards a moderate increase of the ratio in the latter condition. (In the data of Fitz and Van Slyke (4) the normal urines show, as do the normal data of the present paper, a mean $\mathrm{NH}_{3}$ /acid ratio of approximately 1.5 while the mean for the cases with ketosis is 2.2. This difference in the ratio is small, however, considering the immense range of total $\mathrm{NH}_{3}$ + acid values covered.) The eliminated acid is divided between ammonium salts and free acid with a sufficient degree of constancy to justify the definition of the usual limits of the $\mathrm{NH}_{3}$ / acid ratio in the urine of normal individuals, and the assumption of an abnormality in the acid excreting mechanism when this ratio consistently lies outside such limits, A persistent abnormally high ratio may result - from bacterial formation of ammonia from urea in the bladder. A persistent abnormally low ratio is presumably a sign of damage to the ammonia-forming function, particularly when the titratable acid factor of the ratio appears unaffected.

Henderson and Palmer $(12,11)$ determined the free acid by ti-

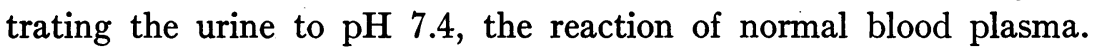
The $\mathrm{NH}_{3} /$ acid ratio ${ }^{1}$ averaged over a number of days in the urine of normal subjects varied from 0.7 to 2.0. Nephritic cases fell into 2 groups.

${ }^{1}$ Henderson and Palmer expressed their results by the ratio acid/ $/ \mathrm{NH}_{3}$. We have inverted this ratio and use the expression $\mathrm{NH}_{3}$ /acid, because (1) the relative rise and fall in the ammonia appears to be the significant factor in varying nephritic conditions, the free acid excretion being relatively unaffected. With the ammonia in the numerator, therefore, the ratio rises and falls with the more 
Among the cases with normal ratios there was a predominance of conditions diagnosed as degenerative nephritis. In another group, more sharply definite in regard to urinary character, the $\mathrm{NH}_{3} /$ acid ratio varied from 0.3 to 0.6 , these low values being due to diminished ammonia output. On the average in this group of cases the urine volume was abnormally great, its $\mathrm{pH}$ unusually low, and the "total acid output" $\left(\mathrm{NH}_{3}+\right.$ acid) diminished because of deficit in the $\mathrm{NH}_{3}$ constituent. The low urinary $\mathrm{pH}$ was interpreted to indicate a tendency towards nephritic acidosis, presumably caused by the reduced ammonia formation. In this group chronic glomerulonephritis was prominent.

Stillman, Van Slyke, Cullen, and Fitz (31) reported from this hospital a case of acute nephritis following pneumonia in which there was almost complete suppression of ammonia excretion, and a progressive fall in blood alkali reserve. When the latter had dropped to about half normal, the clinical condition began to improve and the ammonia output gradually increased until it reached the unusual maximum of $1500 \mathrm{cc}$. of $0.1 \mathrm{~N}$ ammonia per day. The daily ammonia excretion then also fell to the usual 300 or $400 \mathrm{cc}$., presumably because there was no further need for unusual acid elimination. (Only the alkali reserve data were published, the present ammonia figures are from the hospital records.)

Rabinowitch (25) has recently shown that in diabetic patients with albuminuria the $\mathrm{NH}_{3}$ / acid ratio averages lower than in normal persons or in diabetic patients without albuminuria. He concludes that diabetics with injured kidneys have a subnormal ability to form ammonia, and are probably rendered thereby unusually susceptible to acid intoxication.

Interest both in the origin of the ammonia of the urine and in its variation in nephritis has been augmented by Nash and Benedict (21) who have shown that the ammonia is probably formed by the kidneys. It had been believed that the ammonia was formed else-

significant variable. (2) The $\mathrm{NH}_{3}$ /acid ratio, as will be shown, is low when kidney function is diminished, and in its relation to renal function it appears simpler to denote ammonia-acid relationship by an expression which parallels the renal function, rather than by one which increases when the function falls. 
where in the body and carried by the blood to the kidneys. The early determinations of ammonia in blood, with the exception of those of Folin and Denis (5), were compatible with this hypothesis. Nash and Benedict found that when minute precautions were taken the blood from the carotid and vena cava of dogs contained less than 0.1 mg. of ammonia nitrogen per $100 \mathrm{cc}$. The blood from the renal vein, however, contained about twice as much, a fact which strongly suggested that the kidneys are the site of the ammonia formation. Loeb, Atchley and Benedict (18) have repeated and confirmed these observations. ${ }^{2}$

In this paper we present the results of routine determinations of the $\mathrm{NH}_{3}$ /acid ratio carried out on nephritic patients over a period of several years. (Many of the patients reported in this paper have been included in previous papers on other phases of nephritic metabolism $(14,15,16,17)$. Blood ammonia determinations on a number of patients and on normal subjects have been made to determine whether the low ammonia excretions observed in the former were due to diminished formation or to retention.

An attempt has been made to correlate the variations in the $\mathrm{NH}_{3} /$ acid ratio with the type and severity of the cases.- The latter have been classified according to the plan of Volhard and Fahr (15, 35, 36) in four groups, nephrosis, acute glomerulonephritis (stage I), chronic glomerulonephritis (stages II, and III), and nephrosclerosis. Each type is reported in a table by itself, and in each table the cases are arranged as far as possible in the order of increasing severity, as judged by the clinical state and renal function tests. We realize that the Volhard-Fahr types are not separated by sharp lines, and that topinions are likely to differ in classifying certain cases. We have given in the tables such data as space permits to assist the reader in forming his own judgment.

${ }^{2}$ Strauss (32), using the vacuum distillation method of Hahn and Kootz (9) reported the normal blood ammonia nitrogen as 0.8 to $2.0 \mathrm{mg}$. per $100 \mathrm{cc}$. and nephritic values ranging up to $6 \mathrm{mg}$. Gherardini (8) reported 0.4 to $0.7 \mathrm{mg}$. in both normal and nephritic subjects. Such high values seem explainable only by errors of technique. 


\section{EXPERIMENTAL}

The analyses of nephritic urine were carried out on 24-hour specimens which had been preserved with toluene in an ice box from the time the individual specimens were obtained. In some cases 24-hour urine specimens were examined daily. In others they were taken every second day or once each week. In the series of determinations on normal individuals the specimens were collected over periods generally of about 2 hours, and analysed immediately.

Methods. Urinary ammonia was determined as described by Van Slyke and Cullen (33), $5 \mathrm{cc}$. of urine being mixed with $5 \mathrm{cc}$. of saturated potassium carbonate solution and aerated into standard acid.

The titratable acidity of the urine was determined by Folin's familiar method (6). Because the neutrality of our solid potassium oxalate could not be trusted, we have used instead of the solid substance prescribed in the original method, a saturated solution neutralized to phenolphthalein. Fifteen cubic centimeters of this solution and $\mathbf{0 . 5}$ cc. of 1 per cent phenolphthalein solution were added to $25 \mathrm{cc}$. of urine; the mixture was thoroughly shaken, and was titrated to a pink color ( $\mathrm{pH}$ approximately 8.5) with $0.1 \mathrm{~N} \mathrm{NaOH}$. Henderson and Palmer $(12,11)$ used neutral red as indicator and $\mathrm{pH} 7.4$ as end point, a procedure which has an advantage in physiological interpretation in that the results express the amount of alkali required to bring the urine to the $\mathrm{pH}$ of normal blood serum. For the purpose of ascertaining the $\mathrm{NH}_{3}$ /acid excretion ratio, however, we have preferred the phenolphthalein titration because its more alkaline end point represents a urinary reaction at which the ammonia excretion becomes very small. Even in urine alkaline to phenolphthalein there is, it is true, some ammonia, and in consequence a urine with a $\mathrm{pH}$ of 8.5 would yield an $\mathrm{NH}_{3}$ /acid ratio of infinity. When the amount of $0.1 \mathrm{~N}$ alkali required for $25 \mathrm{cc}$. of urine falls below $1 \mathrm{cc}$. the $\mathrm{NH}_{3} /$ acid ratio may accordingly be higher than in urine of more usual acid content excreted by the same individual. The interpretation of the physiological and clinical significance of the ratio in such urines is therefore uncertain. They are, however, rare.

No attempt has been made to prevent escape of $\mathrm{CO}_{2}$ from the urine. We have preferred to perform the titrations under conditions that 
would be a practicable part of hospital routine, and to permit such increase in the margin of variation as might result. In any but the most alkaline urines the effect could not be important.

The blood ammonia. Five cubic centimeters of oxalated blood were transferred, within three minutes of the time of drawing, into the test tube of the Van Slyke-Cullen apparatus used for urea estimations, in which the rubber connections were as short as possible. An equal volume of saturated potassium carbonate, from which the ammonia had been almost completely removed by aeration for one hour, was added. A flowmeter (22) was connected, and the contents of the tubes were aerated for 5 minutes with an air current flowing at the rate of 5 liters per minute. (Van Slyke and Cullen found that with this time and air current 98 per cent of the ammonia was removed.) The ammonia was caught in a tube, calibrated at $25 \mathrm{cc}$., containing $1 \mathrm{cc}$. of $0.005 \mathrm{~N}$ acid diluted to about $15 \mathrm{cc}$. with ammonia-free water. As indicator we used 4 drops of a saturated solution of methyl red in 70 per cent alcohol, as suggested by Barnett (2). At the end of the aeration the tubes were washed down and diluted to $25 \mathrm{cc}$. with ammonia-free water. The excess acid was titrated with $0.005 \mathrm{~N}$ alkali to a standard end point color, by which all the solutions had been standardized. For this end point a buffer mixture of $\mathrm{pH} 5.6$, made by mixing $91 \mathrm{cc} \frac{\mathrm{M}}{5}$ sodium acetate and $9 \mathrm{cc} \frac{\mathrm{M}}{5}$ acetic acid, was used. The standard color was that of $25 \mathrm{cc}$. of this mixture to which 4 drops of indicator had been added. The titrations were made from a 2 cc. micro burette, so that the volumes delivered could be measured to within $0.005 \mathrm{cc}$. Blank determinations were performed on the reagents, and the amount of ammonia obtained from them was deducted from that found in the blood analyses. The accuracy of this method is shown in table 1 .

Table 2 shows that all of the measurable ammonia of the blood is aerated in the first 5 minutes when the rate of air flow is 5 liters per minute (controlled by a flowmeter). Further aeration, up to $40 \mathrm{~min}$ utes, gave no more ammonia, which proves that the potassium carbonate did not react with any constituent of the blood to produce ammonia. In fact the carbonate prevents the spontaneous ammonia formation that occurs in drawn blood. This spontaneous formation, 
TABLE 1

Recovery of ammonia from standard ammonium sulfate solutions by the blood ammonia method

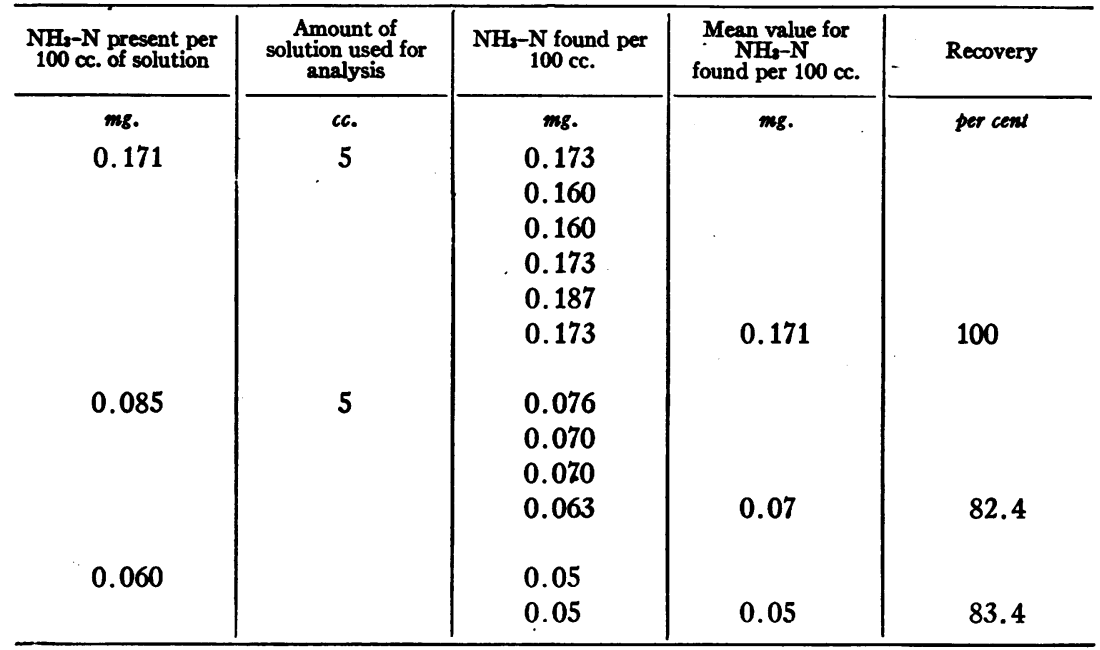

TABLE 2

Effect of aeration time and delay in analysis on blood ammonia determination

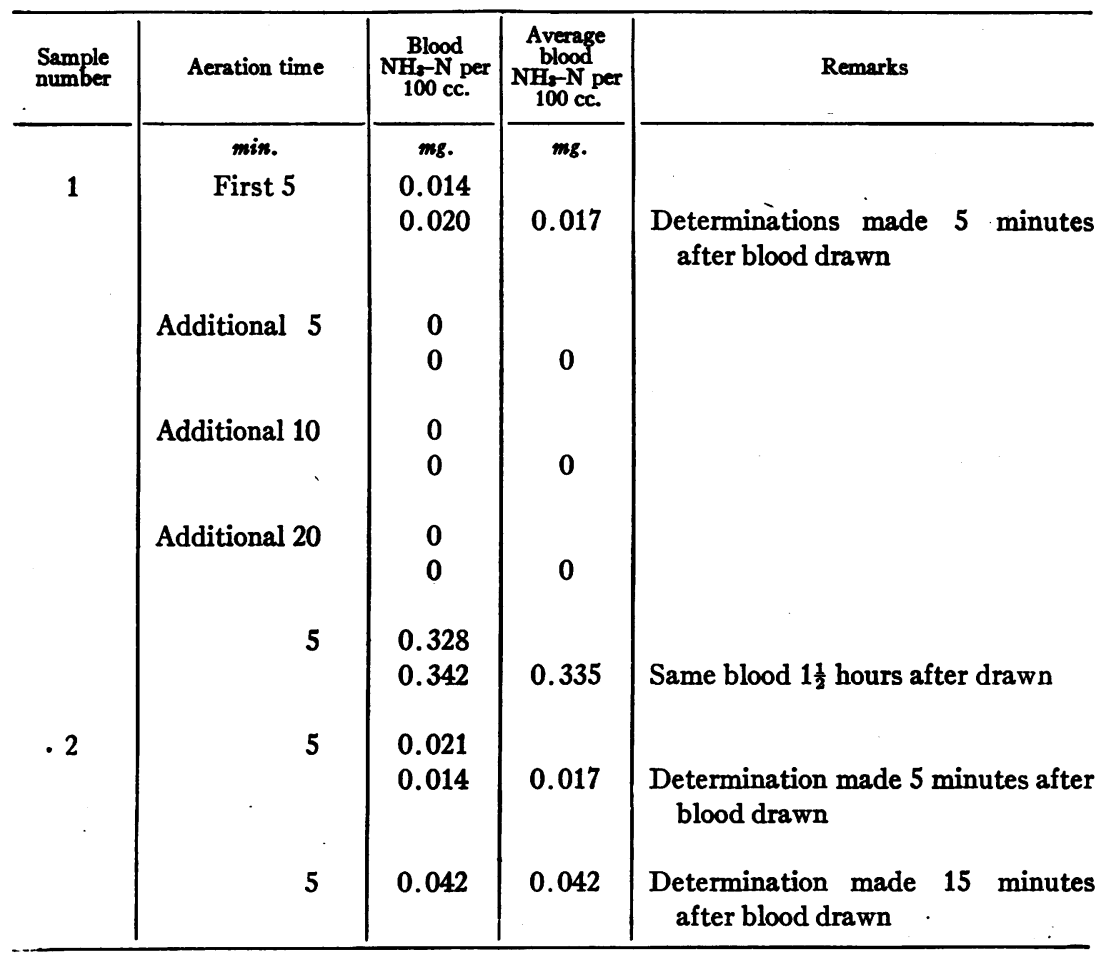


already noted by Parnas and Heller $(23,24)$, makes it important to add the carbonate to the blood immediately on drawing. The ammonia value may be doubled when the blood stands 15 minutes without addition of carbonate. If the blood is analyzed after standing $1 \frac{1}{2}$ hours the increase may be 17 fold.

Blood urea determinations were made according to the method of Van Slyke and Cullen (33).

The urea concentration index was calculated from the urea content of blood and urine by a modification of the original method of Austin, Stillman, and Van Slyke. The present index ${ }^{3}$ is calculated as

$$
\frac{\text { Urine urea concentration }}{\text { Blood urea concentration }} \times \sqrt{\text { cc. urine volume output per minute }}=\frac{U}{B} \sqrt{V}
$$

The simple concentration ratio $\frac{U}{B}$ represents the number of times the kidney concentrates the urea in compressing it from blood concentration, $B$, to urine concentration, $U$, when the urine volume output is the average normal $1 \mathrm{cc}$. per minute ( $=1440 \mathrm{cc}$. per 24 hours). When the urine volume is less than $1 \mathrm{cc}$. per minute, the concentration $U$ will normally be greater, and vice versa. In order to correct for this volume effect we multiply the simple ratio $\frac{U}{B}$ by the square root of the volume, an empirical correction which was found to hold for ordinary urine volumes (under $2 \mathrm{cc}$. per minute) by Austin, Stillman, and Van Slyke). In order to apply the formula to subjects of different weights, we have used the volume per kilo body weight, $\frac{V}{W}$,

${ }^{3}$ The present formula is identical with that of Austin, Stillman, and Van Slyke, but is rearranged into concentration terms for convenience in calculation and interpretation. The former equation was $K=\frac{D}{B \sqrt{V W}}$, where $D$ is the output of urea per time unit, $B, V$, and $W$ having the same significance as above. The output, $D$, is the product of the volume, $V$, and the concentration, $U$. Hence $D=U V$. Substituting $U V$ for $D$ we have $K=\frac{D}{B \sqrt{V W}}=\frac{U V}{B \cdot \sqrt{V W}}=$ $\frac{U}{B} \sqrt{\frac{V}{W}}$. A more detailed account of the use of the concentration index will be given shortly in another paper (20). 
instead of the absolute volume. In this case we have used the cc. hourly output as $V$, since for adults of average size, $W$ is about 60 , and $\frac{\text { cc. per hour }}{\text { body weight }}$ approximates cc. per minute.

The concentration index $\frac{U}{B} \sqrt{ } \bar{V}$, or with the weight correction $\frac{U}{B} \sqrt{\frac{V}{W}}$, varies from 35 to 80 in normal subjects. Occasionally a single determination as low as 30 may be encountered, but we have observed no normal subjects with an index repeatedly and consistently below 35. That is, the normal adult, excreting urine at the average normal rate of $1 \mathrm{cc}$. per minute, concentrates urea in the urine to at least 35 times the blood concentration, usually between 40 and 60 . The numerical values of the index with the present units of volume are 6.5 times as great as the values with the units used in the Austin. Stillman, .Van Slyke index, which varied in normal subjects from 4.5 to 10.5 .

The phenolsulphonephthalein output was determined as described by Rowntree and Geraghty (27). The injections were made intravenously, and a fresh standard was prepared for each test.

The serum $\mathrm{CO}_{2}$ content was determined according to the method of Van Slyke and Neill (34).

The serum $p H$ was determined according to the method of Hastings and Sendroy (10).

To avoid reporting individually a large number of observations on patients, the daily acid and ammonia excretions have been averaged for periods of several weeks or months. Changes in diet, treatment, or in the state of renal function were taken as reasons for starting new periods.

\section{ANALYSIS OF RESULTS}

Normal subjects. (Table 3 and fig. 1.) Ninety-five determinations of the ammonia-acid ratios were made on 11 normal subjects. The collection of specimens was generally made over 2-hour periods in the course of the day. No attempt was made to control the diet, fluid intake, or activity of these subjects. The volume, specific gravity, and the absolute amounts of ammonia and acid excretion varied consider- 
TABLE 3

The ammonia-acid ratio of normal individuals

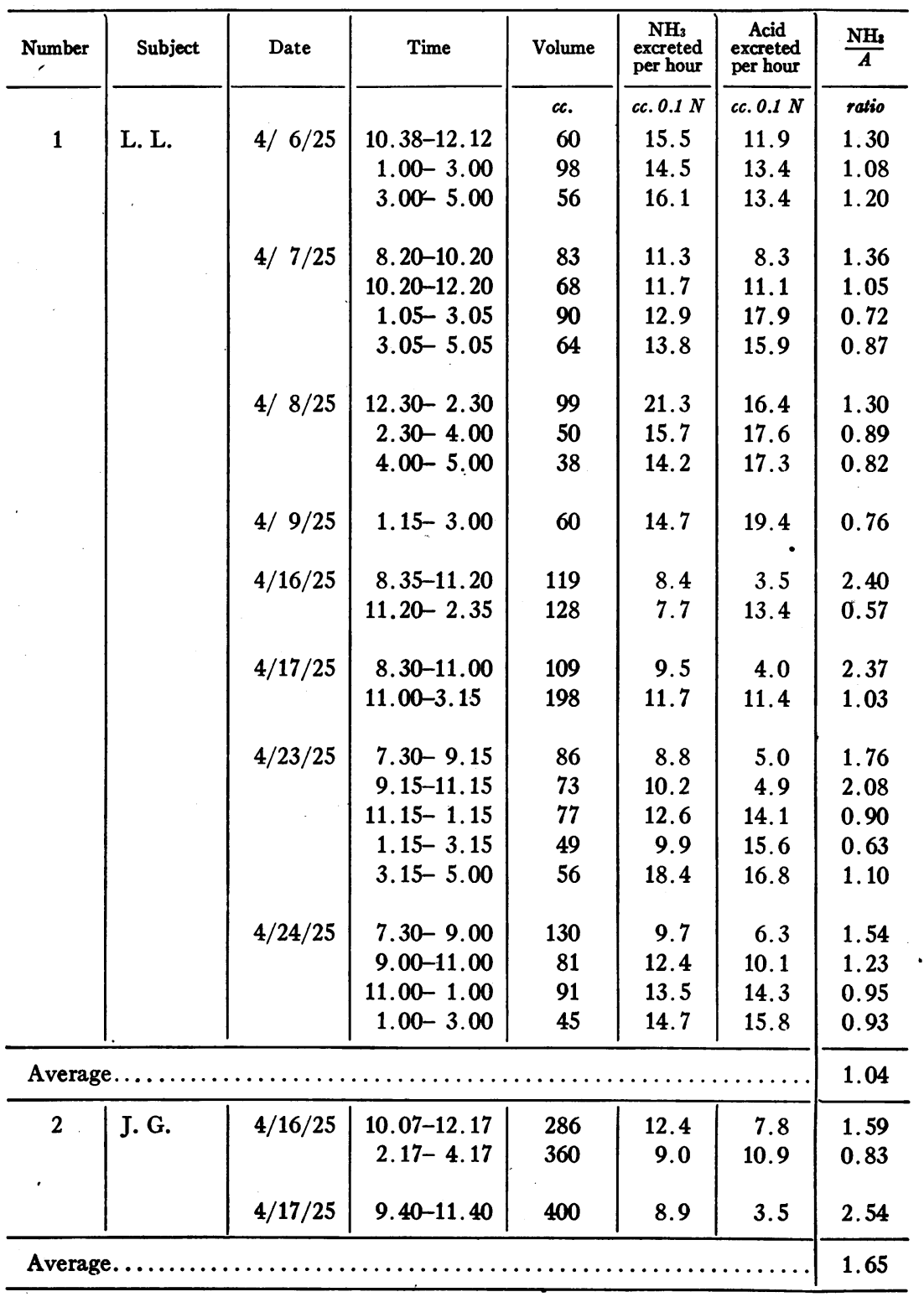


VAN SLYKE, LINDER, HILLER, LEITER, MCINTOSH

TABLE 3-Contivered

\begin{tabular}{|c|c|c|c|c|c|c|c|}
\hline Number & Subject & Date & Time & Volume & $\begin{array}{c}\mathrm{NH}_{3} \\
\text { excreted } \\
\text { per hour }\end{array}$ & $\begin{array}{c}\text { Acid } \\
\text { excreted } \\
\text { per hour }\end{array}$ & $\frac{\mathrm{NH}_{3}}{A}$ \\
\hline \multirow{13}{*}{3} & \multirow{13}{*}{ J. C. B. } & $4 / 8 / 25$ & $2.30-4.00$ & $\begin{array}{l}c c . \\
55 .\end{array}$ & $\begin{array}{c}\text { cc. } 0.1 \mathrm{~N} \\
25.9\end{array}$ & $\begin{array}{c}c c .0 .1 \mathrm{~N} \\
14.9\end{array}$ & $\begin{array}{l}\text { ratio } \\
1.74\end{array}$ \\
\hline & & $4 / 9 / 25$ & $2.00-3.33$ & 42 & 29.9 & 16.8 & 1.78 \\
\hline & & $4 / 16 / 25$ & $11.45-1.45$ & 64 & 24.7 & 14.1 & 1.75 \\
\hline & & $4 / 17 / 25$ & $10.30-12.00$ & 116 & 18.0 & 7.3 & 2.47 \\
\hline & & & $12.00-2.10$ & 118 & 20.2 & 12.5 & 1.62 \\
\hline & & $4 / 23 / 25$ & $6.40-9.00$ & 143 & 23.0 & 12.5 & 1.84 \\
\hline & & & $9.00-11.00$ & 157 & 12.4 & 3.7 & 3.35 \\
\hline & & & $11.00-1.00$ & 78 & 15.2 & 11.8 & 1.29 \\
\hline & & & $1.00-3.00$ & 52 & 21.5 & 14.7 & 1.46 \\
\hline & & & $3.00-4.30$ & 43 & 14.3 & 9.1 & 1.52 \\
\hline & & $4 / 24 / 25$ & $7.15-9.15$ & 60 & 19.0 & 10.7 & 1.78 \\
\hline & & & $9.15-11.15$ & 73 & 19.6 & 6.7 & 2.93 \\
\hline & & & $11.15-3.15$ & 165 & 37.5 & 18.3 & 2.05 \\
\hline \multicolumn{7}{|c|}{ Average. } & 1.97 \\
\hline \multirow[t]{4}{*}{4} & \multirow[t]{4}{*}{ J. W. } & $4 / 11 / 25$ & $9.00-11.00$ & 107 & 34.7 & 13.8 & 2.52 \\
\hline & & $4 / 16 / 25$ & $8.00-10.00$ & 435 & 139.0 & 144.0 & 0.96 \\
\hline & & & $2.00-4.30$ & 72 & 30.7 & 26.6 & 1.15 \\
\hline & & $4 / 17 / 25$ & $1.00-2.30$ & 111 & $34: 0$ & 35.1 & 0.97 \\
\hline \multicolumn{7}{|c|}{ Average. } & 1.40 \\
\hline \multirow[t]{4}{*}{5} & \multirow[t]{4}{*}{ F. C. } & $4 / 11 / 25$ & $9.00-11.00$ & 64 & 22.2 & 7.5 & 2.96 \\
\hline & & & $10.30-11.05$ & 33 & 26.8 & 13.7 & 1.96 \\
\hline & & & $3.00-4.00$ & 40 & 26.3 & 12.6 & 2.09 \\
\hline & & $4 / 17 / 25$ & $9.20-11.20$ & 78 & 17.7 & 7.5 & 2.36 \\
\hline \multicolumn{7}{|c|}{ Average. } & 2.34 \\
\hline \multirow[t]{3}{*}{6} & W. N. & $4 / 6 / 25$ & $11.00-1.00$ & 360 & 29.9 & 18.6 & 1.61 \\
\hline & & & $1.00-3.00$ & 290 & 42.7 & 33.6 & 1.27 \\
\hline & & & $3.00-5.00$ & 265 & 38.4 & 24.2 & 1.59 \\
\hline
\end{tabular}


TABLE 3-Continued

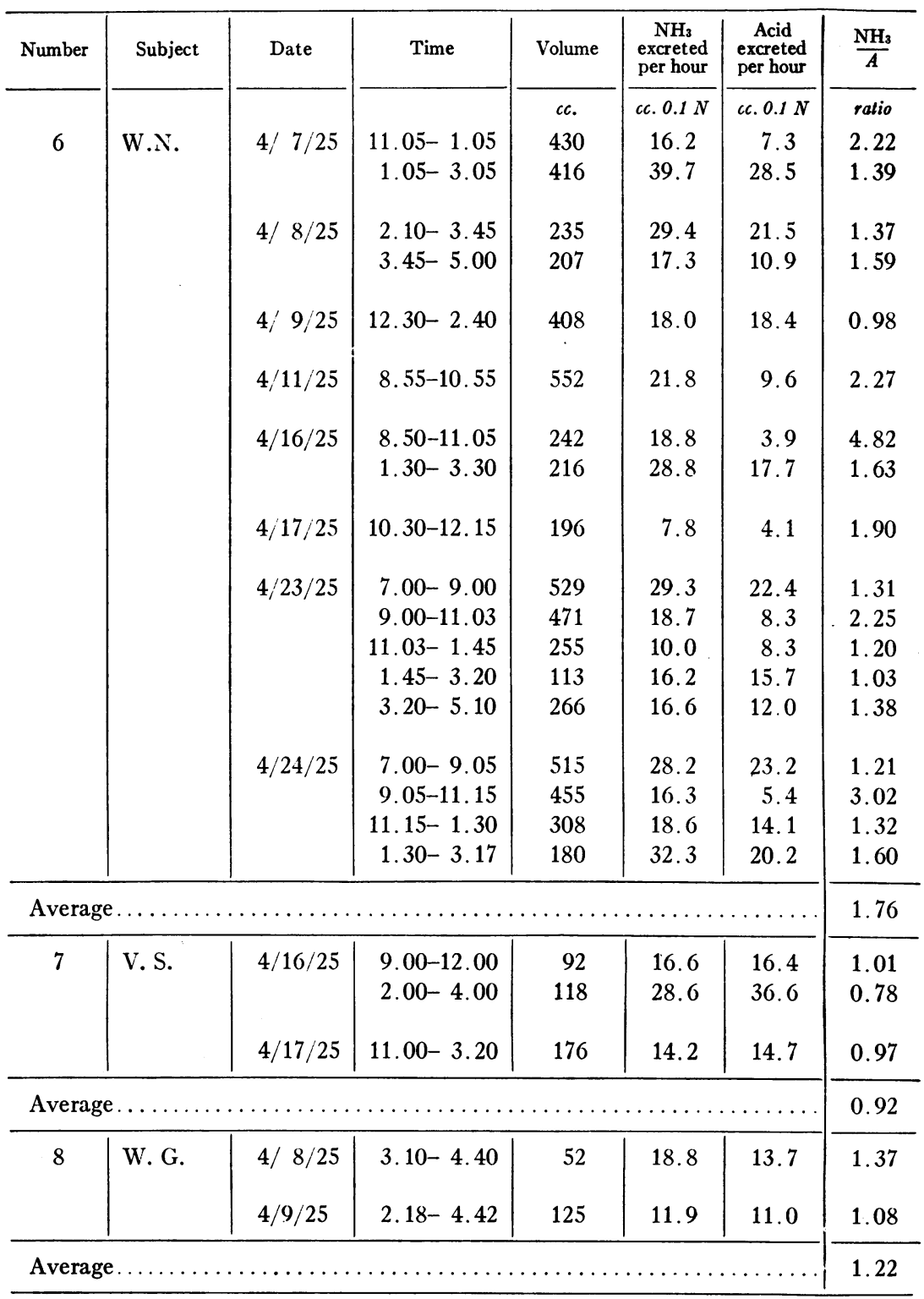


VAN SLYKE, LINDER, HILLER, LEITER, MCINTOSH

TABLE 3-Concluded

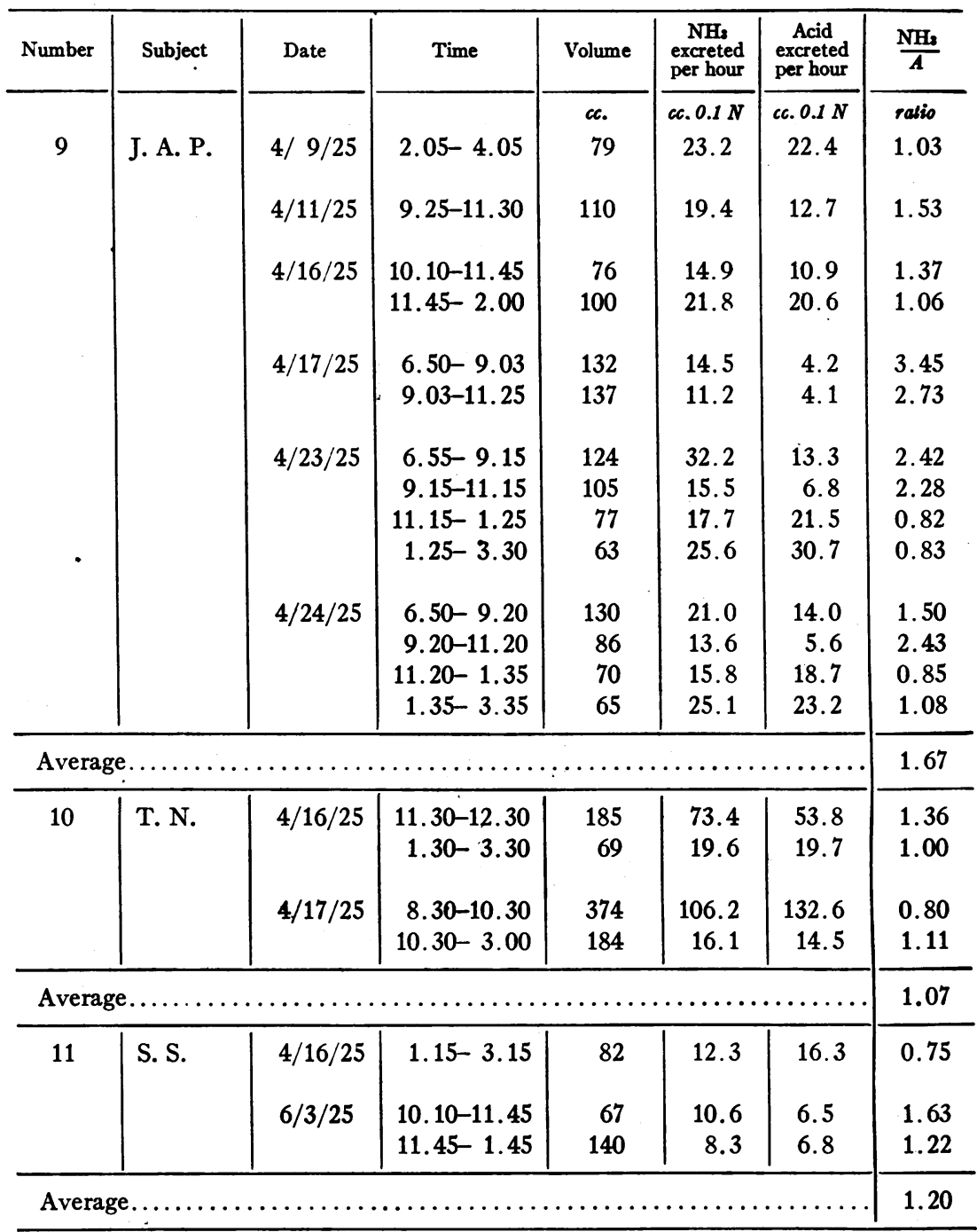

ably. The ratios varied between the extremes 0.6 and 4.9 , but the majority fell between 0.8 and 2.5. The mean individual ratios fell between 0.9 and 2.3, the majority lying between 1.0 and 2.0, similar to those of Henderson and Palmer (13). Normal individuals show for ammonia and acid excretion the wide flexibility which seems char- 
acteristic for normal kidney function. For this reason, isolated estimations are of little value; the variability of the function is important as well as the value of the ratio.

Nephrosis. (Six cases, table 4 and fig. 1.) The patients in this

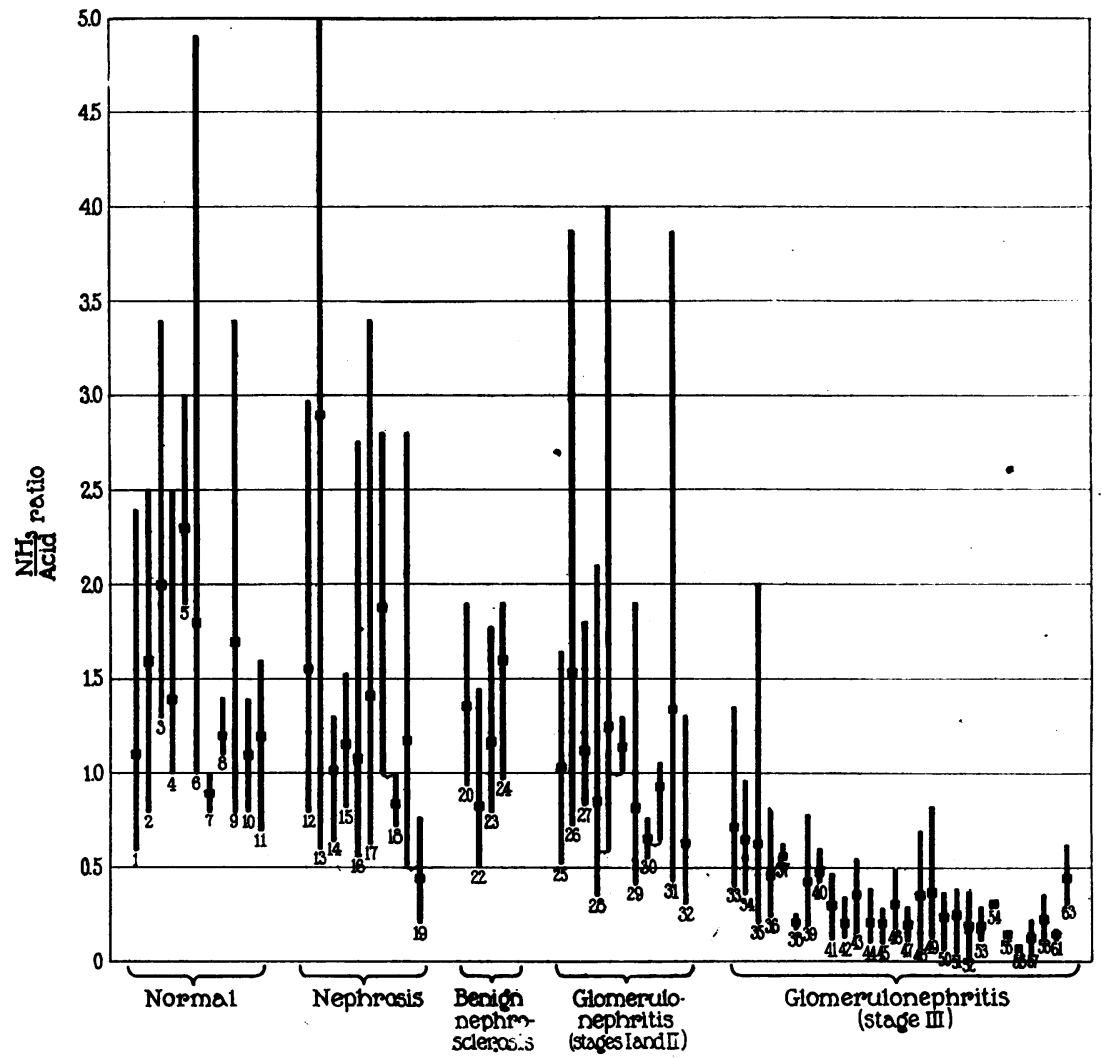

FIg. 1. The lines represent the entire range of ammonia-acid ratios for each case. The solid blocks represent the mean ratios. Two or more lines joined by a bracket represent different states of renal function in the same patient, as explained in the text. The lines are numbered to correspond with the case numbers in the tables.

group showed normal values for the ammonia-acid ratio. There was the usual variation in range for the individual and the averages. The ratios varied from 0.56 to 5.0 , the majority falling between 0.6 and 2.8. The average of the ratios for the individual cases varied from 1.02 to 2.9 , all but one lying between 1.0 and 2.0. 
In B. S., 13, the ammonia was always high and the acid excretion moderate; consequently, the ratio was high. During the period from March 25 to April 18 large doses of calcium chloride were given after the method of Blum, Aubel and Hausknecht (3); there was a rise in ammonia output which reached a maximum of $1000 \mathrm{cc}$. $0.1 \mathrm{~N}$ solution. This ammonia formation presumably was the protective response of the organism to prevent acidosis from the $\mathrm{HCl}$ absorbed from the administered $\mathrm{CaCl}_{2}$ (Salvesen, Hastings and McIntosh (29)). The calcium chloride had no effect on the edema. Between May 20 and June 14 a high protein, low fat diet was given. The protein was increased from 40 to 80 grams, and thence by successive additions to 140 grams, i.e., 4.4 grams per kilo body weight. Analysis of the diets of Sherman's tables (30) shows that the excess of acid radicles over basic was increased from $80 \mathrm{cc}$. of decinormal acid to approximately $400 \mathrm{cc}$. An increase in the output of acid and ammonia followed, but, whereas the calcium chloride produced a large increase of ammonia and a small increase of acid, the high protein diet produced a smaller output of ammonia but a larger increase of acid. A year later, during a relapse, both the titratable acidity and the ratio were still high.

In another case, M. R. (17), the administration of 5 to 10 grams of calcium chloride daily had a similar effect in increasing the ammonia-acid ratio, due to the excess excretion of ammonia over acid radicles. In this patient the $\mathrm{pH}$ and bicarbonate of the serum remained normal as a result of this compensatory mechanism.

In another case, G. H., 14, the lack of effect of sodium chloride is shown, where the ratio remained fairly constant, as did the absolute figures.

In nephrosis, therefore, the kidney function as regards ammonia and acid excretion is normal. This finding is in accord with the normal ability of the kidney to excrete and concentrate urea.

Table 5 shows 2 cases, B. F., and S. J., which came under observation with some of the characteristics of nephrosis, and later apparently developed renal insufficiency. In B. F., probably complicated by some other underlying condition, possibly Addison's disease, a change during the course of observation was indicated by $a$ fall in the index of urea concentration and phthalein output. A definite drop in the ammonia-acid ratio, with a tendency to fixation, ran parallel with these findings, although the ratio was still within the lower limit of the normal. The case S. J. was under observation during two different admissions to the hospital. During the first period the ammonia-acid ratio was over 1; during the second period there were signs of definite functional impairment, and the ratio had fallen to 0.54 , and finally to 0.32 , at which time there was a fixation at that low value. The change in the variability of the ratio during these two periods is strikingly illustrated in figure 1 , where the first column for this patient shows a fluctuation of ratio from 0.52 to 2.8 , and the second from 0.24 to 0.76 . 


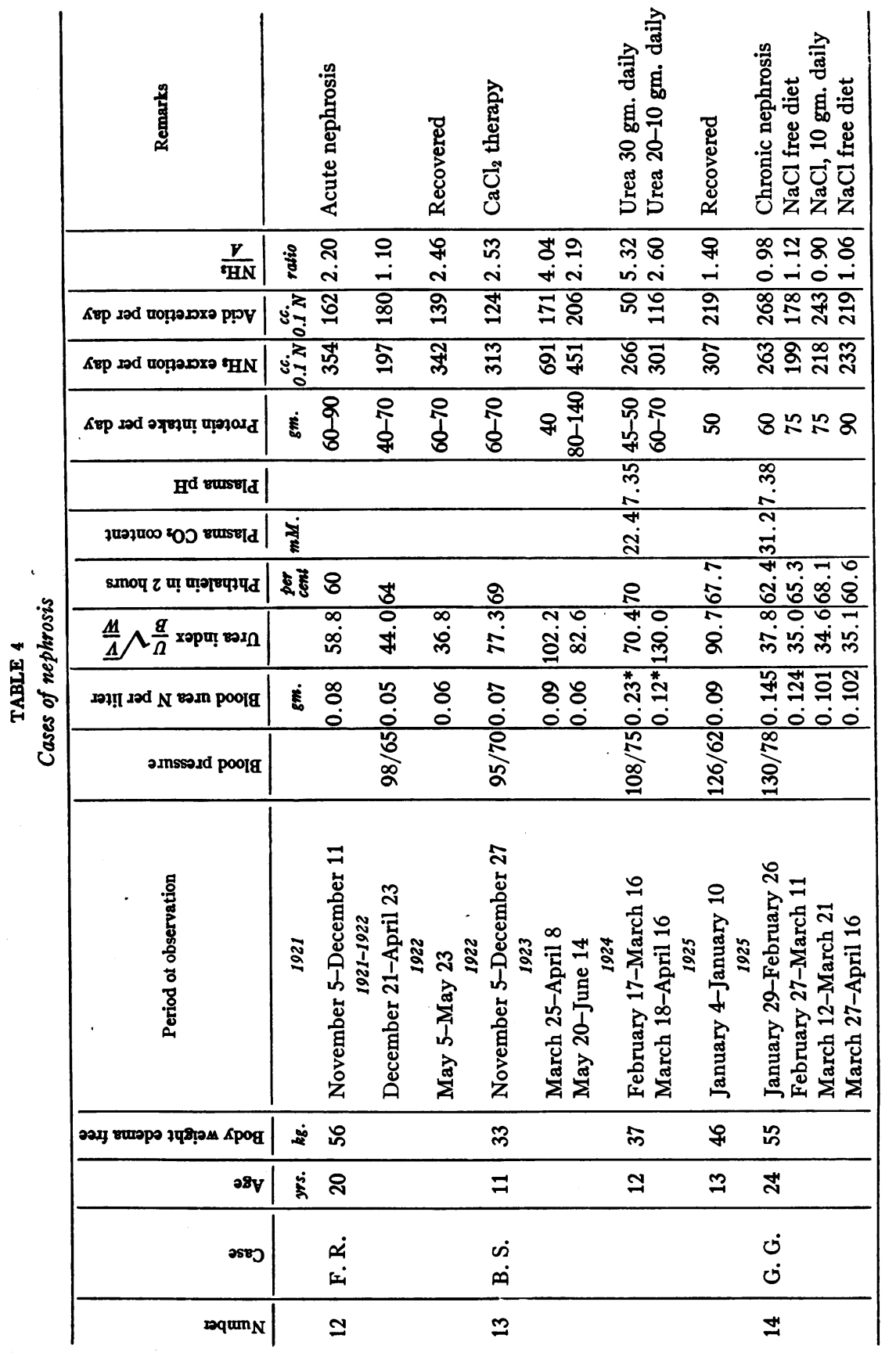




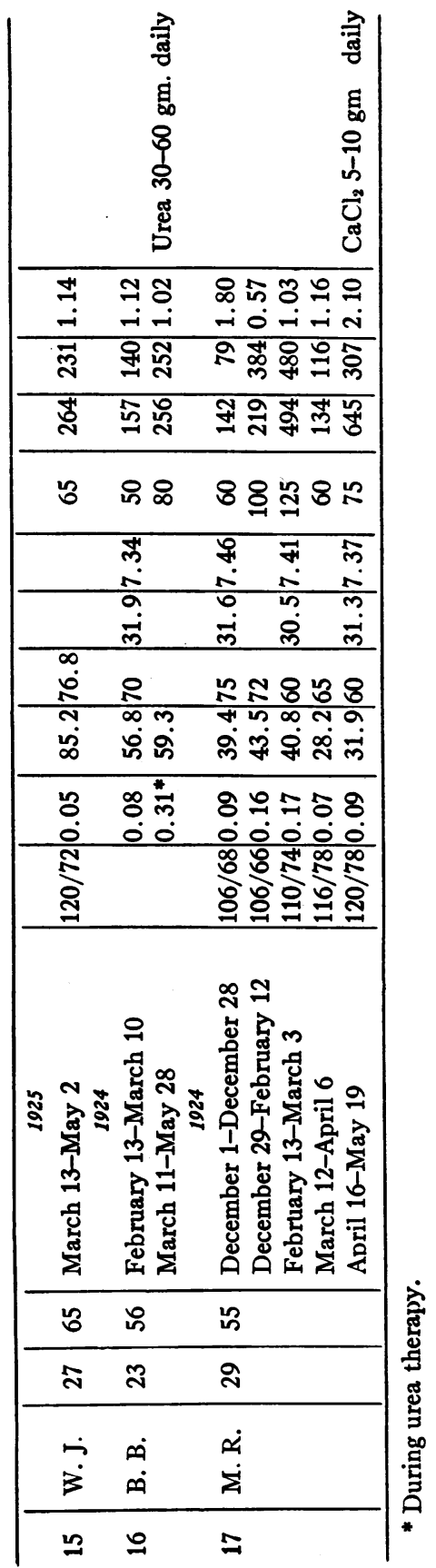




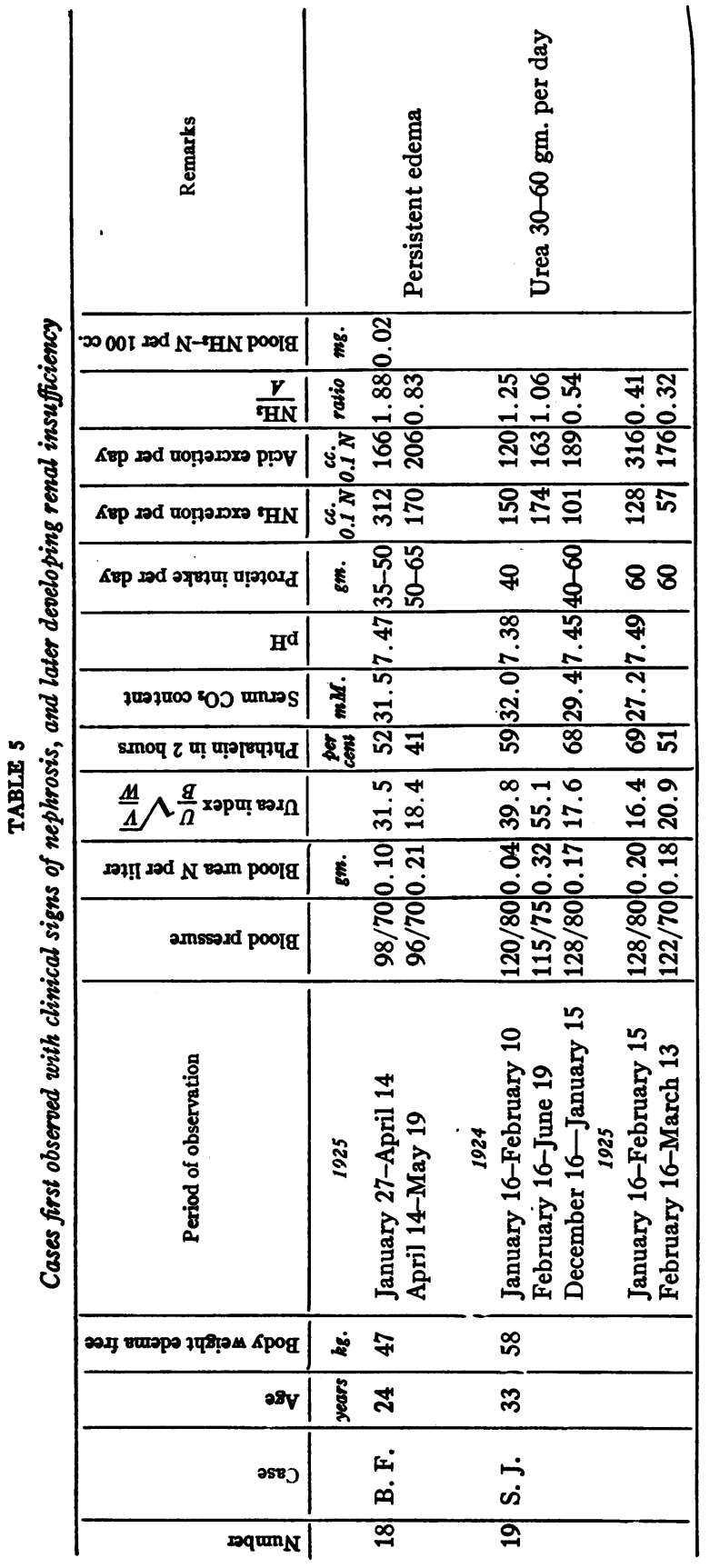


VAN SLYKE, LINDER, HILLER, LEITER, MCINTOSH

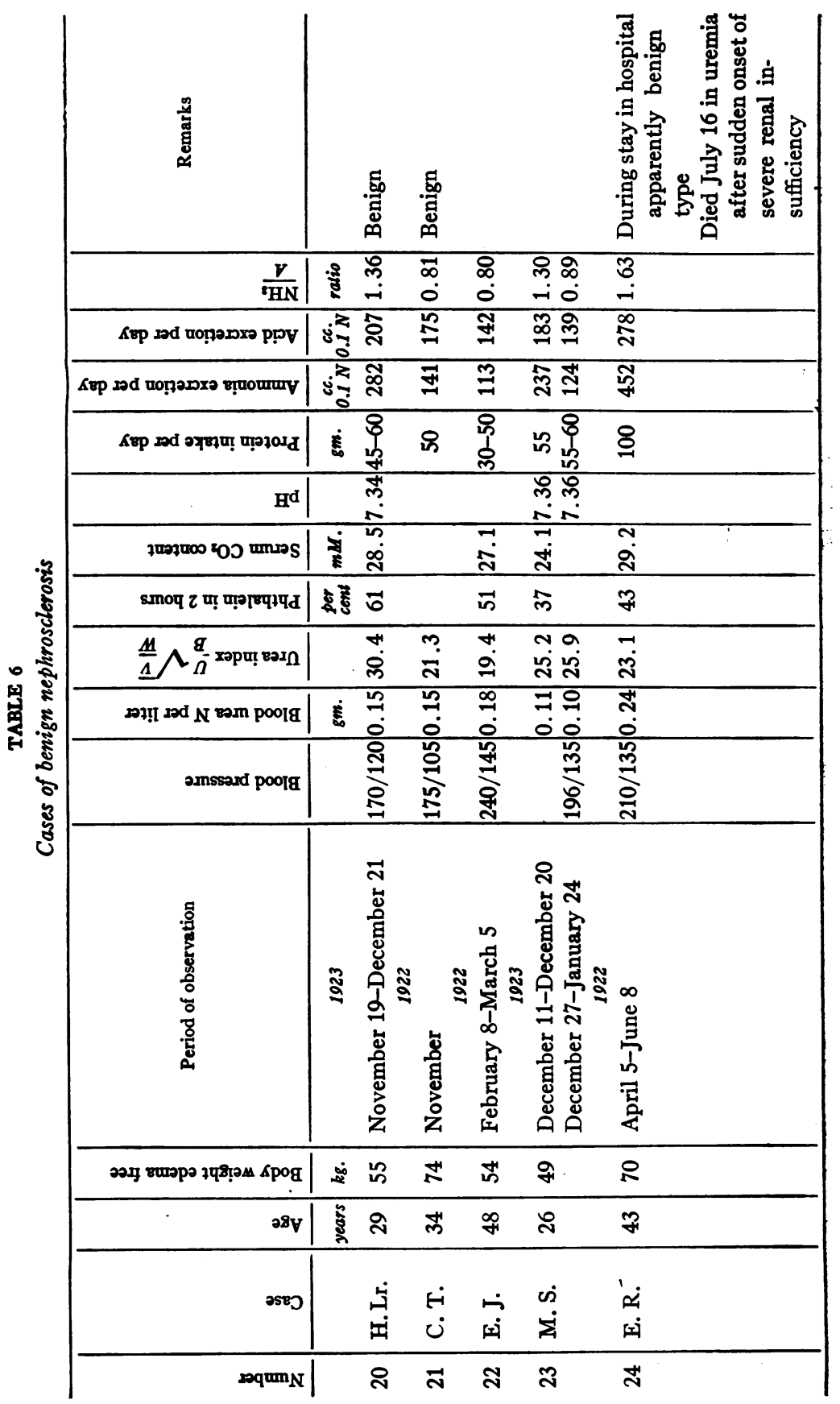


Benign nephrosclerosis. (Five cases, table 6 and fig. 1.) All of these patients had only moderately diminished renal function as indicated by the urea concentration index. The $\mathrm{NH}_{3}$ /acid ratios varied from 0.5 to 1.9 , with the averages from 0.83 to 1.6. These average values are within the limits of normality, but it is seen from figure 1 that the range of variation is much less than that of normal subjects.

Glomerulonephritis, stage I (acute) and stage II. (Eight cases, table 7 and fig. 1.) In this group are included some patients who recovered completely, some with residual albuminuria and slight hematuria, and others with edema and urinary findings such as to warrant the possibility of transition into the chronic stages. However, in all these patients the history is definitely that of an acute onset, and the findings at the end of the period of observation are compatible with normal kidney function. The ratios in this group range from 0.31 to 4.0 , the majority lying between 0.6 and 2.0, with averages from 0.62 to 1.53 .

The first 2 cases, W. K., 25, and D. L., 26, were comparatively mild, yet their ratios increased during the course of recovery.

D. G., 28, was a severe case with marked edema (20 kilos over weight), low urea concentration index and phthalein output, increased blood urea, and some anemia. During this period the ammonia-acid ratio averaged 0.87 , which is within the normal limits and, apparently, a discrepancy in view of the other findings. However, the ratio varied considerably, at times falling far below the normal limit. This variation is interesting in view of the ultimate outcome, because the patient suddenly eliminated all the edema, at which time the blood urea, urea index, and phthalien output, and hemoglobin returned to normal, while the ammonia-acid ratio increased to the usual normal value, without recurrence of the low figures. Further observations are desirable to determine the prognostic value of the variable but lowered ratio.

B. Bl., 30, was a moderately severe case which had a low normal function at the time of admission but later became normal. During the first period the ammonia-acid ratio averaged 0.65 and was decidedly fixed between 0.54 and 0,76 . Later it rose to 0.93 .

The output of acid and ammonia was a little low in the patient L. S., 31, during the acute stage of his illness. At the time that the edema was eliminated, the ammonia output increased and there was a temporary decrease in acidity with a rise in the ratio.

E. A., 32, showed a ratio that was persistently at the lower limit of normal, although all other functional tests were normal. Further observation is neces- 
sary in order to determine the significance of such values in the face of otherwise normal functional and good clinical condition. E. A. may exemplify a type of case in which a fixed low normal ammonia-acid ratio is the only evidence of functional disturbance in latent glomerulonephritis following apparent recovery from acute nephritis. The urea index and phthalein output were normal.

Glomerulonephritis, stage III (chronic) and malignant nephrosclerosis. (Thirty cases, tables 8 and 9 and fig. 1.) This group includes patients with chronic diminution of urea concentrating power of all degrees of severity, from the early moderate forms of renal insufficiency to terminal cases with uremia and ability to concentrate only 5 -fold or less. An attempt has been made to arrange them in table 9 according to the state of renal compensation and clinical condition. It is obvious that no sharp lines can be drawn on the basis of any functional tests; yet, on the whole, the milder forms of chronic nephritis have distinctly higher ammonia-acid ratios and urea indices than the more severe and uremic types. As seen from table 8 and figure 1, the first 5 cases showed moderate lowering of the urea index, phthalein output, and ammonia-acid ratio, with moderate nitrogen retention. The average ammonia-acid ratios in the first 6 patients ranged from 0.38 to 0.88 , with one higher terminal value of 1.18 in J. D., who died of septicemia. The remaining cases were of increasing severity. In these the ammonia-acid ratio decreased to a value as low as 0.07 in one case, $\mathbf{M}$. K., 56, and all were below 0.47 , with the exception of S. L., 49, in whom the ratio was 0.6 during one period. In the severe uremic cases, $58,59,60,61$, the ratio paradoxically rose to infinity in the terminal analyses due to an alkaline urine, which in turn may have been due to a terminal bacterial contamination of the urine. The patients were in coma, and the resulting urinary retention, such as occurred in 61 , may have led to bacterial decomposition.

In the group of chronic glomerulonephritis with diminished urea excreting function, there was a striking fixation of the ammonia-acid ratio as well as of the urea index, the only exceptions being in the terminal alkaline urines mentioned above. It can be seen from the table that the low ratios are due to lowered ammonia excretion, never to unusually high daily acid output.

Cases V.S. and N. H., 61 and 62, are glomerulonephritis on a sclerotic basis, which would be classified by Volhard and Fahr as malignant nephrosclerosis. 


\begin{tabular}{|c|c|c|c|c|c|c|}
\hline & 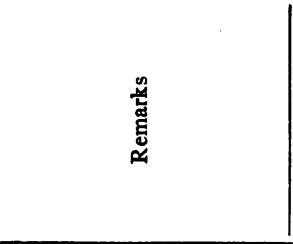 & & 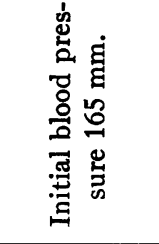 & & 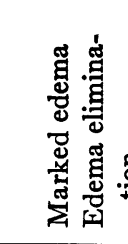 & 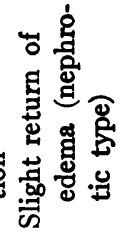 \\
\hline & $500 I$ rd N-8HN poorg & $\dot{0}$ & & & वे & \\
\hline & $\frac{V}{8 \mathrm{HN}}$ & 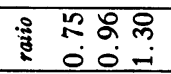 & $\begin{array}{l}8 \text { 영 } \\
0 \stackrel{-1}{-1}\end{array}$ & $\stackrel{\pi}{\dddot{I}}$ & 唡 & $\stackrel{+}{-}$ \\
\hline & 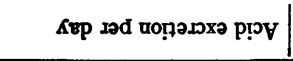 & ن் & ஜำ & $\stackrel{\infty}{\infty}$ & 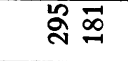 & $\stackrel{n}{n}$ \\
\hline & 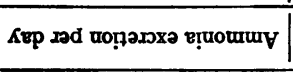 & 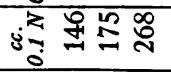 & 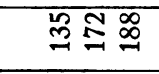 & 읏 & 讨 స్ స్ & $\stackrel{n}{=}$ \\
\hline & 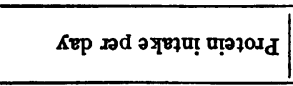 & 염요 & 앙와 안 & 유 & 18 & $\Re$ \\
\hline 8 & $\mathrm{H}^{\mathrm{d}}$ & & $\stackrel{乛}{*}$ & & m. & \\
\hline $\begin{array}{l}\tilde{\omega} \\
\text { है }\end{array}$ & ว"थอ? & 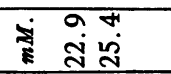 & $\frac{4}{4}$ & & ले & \\
\hline ฐ & 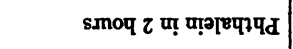 & 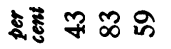 & $\overrightarrow{0}$ & $\ddot{0}$ & ले స్ర & 8 \\
\hline 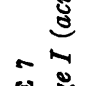 & $\frac{\underline{M}}{\underline{\Lambda}} \wedge \frac{q}{\Omega}$ хәршा вәد & जิ & 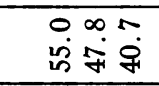 & ֻ̃ & $\begin{array}{l}\cong \infty \\
\approx\end{array}$ & $\frac{0}{0}$ \\
\hline 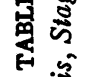 & 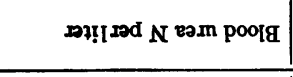 & 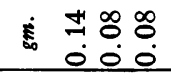 & 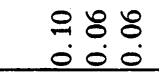 & $\stackrel{0}{:}$ & $\begin{array}{l}38 \\
0 \\
0\end{array}$ & $\begin{array}{l}8 \\
0\end{array}$ \\
\hline है & әmssəad poolg & 응 ஃू & 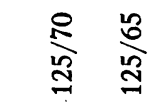 & $\frac{8}{8}$ & 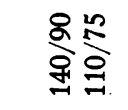 & $\stackrel{?}{\stackrel{\overbrace{}}{\leftrightarrows}}$ \\
\hline 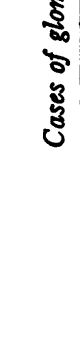 & 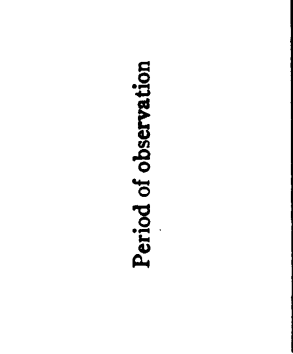 & 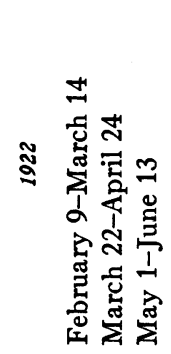 & 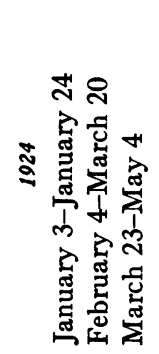 & 空 & 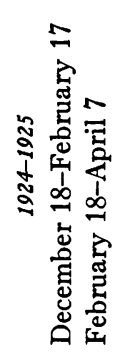 & 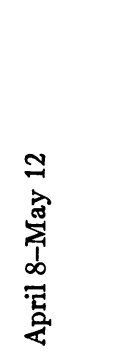 \\
\hline & 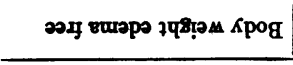 & \& & $\underset{\sim}{\infty}$ & $\stackrel{\infty}{\infty}$ & 伿 & \\
\hline & $28 \mathrm{~V}$ & हू & \pm & 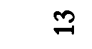 & శ్ల & \\
\hline & 25EJ & $\dot{\vec{k}}$ & $\dot{\oplus}$ & $\dot{ن}$ & $\begin{array}{l}\dot{0} \\
\dot{\theta}\end{array}$ & \\
\hline & səqün $_{N}$ & ผ & ని & $\approx$ & జ్ & \\
\hline
\end{tabular}


VAN SLYKE, LINDER, HILIER, LEITER, MCINTOSH

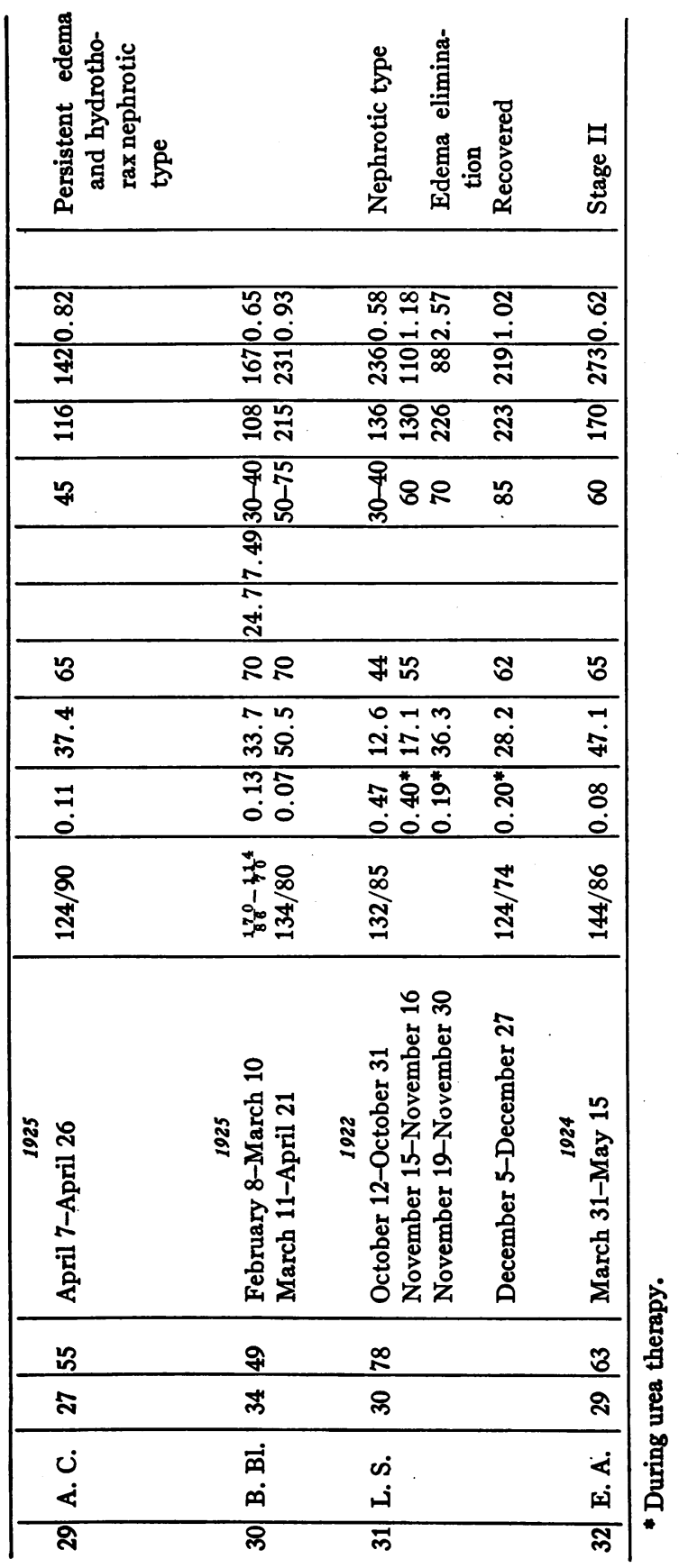


TAB

Cases of glomerulonephritis, Stage

\begin{tabular}{|c|c|c|c|c|c|c|c|c|}
\hline 悹 & छूँ & $\ddot{8}$ & 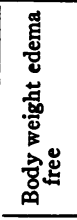 & Period of observation & 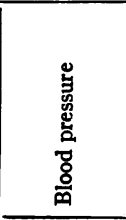 & 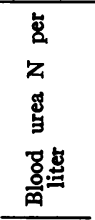 & 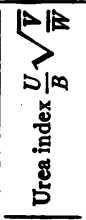 & 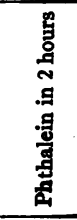 \\
\hline & & years & kg. & 1922 & & mg. & & per cem \\
\hline \multirow[t]{3}{*}{33} & J. D. & 14 & 38 & $\begin{array}{r}\text { May 23-July } 27 \\
1923\end{array}$ & $140 / 78$ & 0.21 & 27.8 & 51 \\
\hline & & & 41 & March 4-March 25 & $120 / 68$ & 0.15 & 24.6 & \\
\hline & & 15 & 42 & November 27-November 29 & $130 / 65$ & 0.23 & 23.9 & 50 \\
\hline \multirow[t]{2}{*}{34} & F. M. & 13 & 33 & $\begin{array}{c}1924 \\
\text { January 31-March } 4\end{array}$ & $\frac{180}{130}-\frac{180}{90}$ & 0.15 & 18.8 & 26 \\
\hline & & & & $\begin{array}{c}\text { March 6-March } 30 \\
\text { April 1-May } 8 \\
1922\end{array}$ & & 0.20 & 10.0 & 31 \\
\hline \multirow[t]{2}{*}{35} & A. Sd. & 40 & 54 & March 5-March 29 & & 0.26 & 17.5 & 49 \\
\hline & & & & $\begin{array}{r}\text { May 15-June } 14 \\
1923\end{array}$ & & 0.57 & 9.0 & 24 \\
\hline 36 & J. O’M. & 16 & 41 & $\begin{array}{c}\text { October 12-December } 24 \\
\text { December 25-March } 27 \\
1922\end{array}$ & $115 / 70$ & $\begin{array}{l}0.43 \\
0.19\end{array}$ & $\begin{array}{l}16.2 \\
20.7\end{array}$ & $\begin{array}{l}51 \\
46\end{array}$ \\
\hline 37 & H. M. & 7 & 18 & $\begin{array}{r}\text { April 8-April } 19 \\
1925\end{array}$ & & 0.40 & 18.4 & 15 \\
\hline 38 & M. G. & 12 & 33 & $\begin{array}{r}\text { May 27-May } 30 \\
1922\end{array}$ & $128 / 74$ & 0.12 & 31.0 & 62 \\
\hline \multirow[t]{2}{*}{39} & H. L. & 10 & 29.5 & May 10-June 5 & $160 / 110$ & 0.18 & 31.6 & 41 \\
\hline & & & 31 & $\begin{array}{c}\text { November 5-November } 30 \\
1924\end{array}$ & $120 / 90$ & 0.44 & 8.4 & 30 \\
\hline 40 & F. P. & 47 & 61.2 & $\begin{array}{c}\text { October 22-November } 26 \\
1924-1925\end{array}$ & $198 / 104$ & 0.32 & 13.2 & 24 \\
\hline \multirow[t]{5}{*}{41} & R. N. & 37 & 58.4 & December 12-January 17 & $150 / 100$ & 0.21 & 20.0 & 46 \\
\hline & & & & January 18-January 31 & $124 / 80$ & $0.32^{*}$ & 24.4 & 60 \\
\hline & & & & February 13-February 24 & $126 / 82$ & 0.27 & 14.9 & 43 \\
\hline & & & & March 4-March 16 & $115 / 80$ & 0.19 & 17.6 & 47 \\
\hline & & & & $\underset{1922}{\text { March 17-April } 16}$ & $130 / 80$ & 0.16 & 18.6 & 31 \\
\hline \multirow[t]{2}{*}{42} & I. C. & 44 & 51 & March 20-April 11 & $130 / 80$ & 0.24 & 17.4 & 50 \\
\hline & & & & $\begin{array}{c}\text { May 18-June } 4 \\
1925\end{array}$ & & 0.31 & 16.2 & 49 \\
\hline \multirow[t]{2}{*}{43} & P. L. & 28 & 57 & January 13-January 29 & $164 / 90$ & 0.31 & 14.8 & 55 \\
\hline & & & & January 30-March 18 & $124 / 74$ & 0.26 & 21.7 & 59 \\
\hline
\end{tabular}

*During urea therapy. 
LE 8

.III, and malignant nephrosclerosis

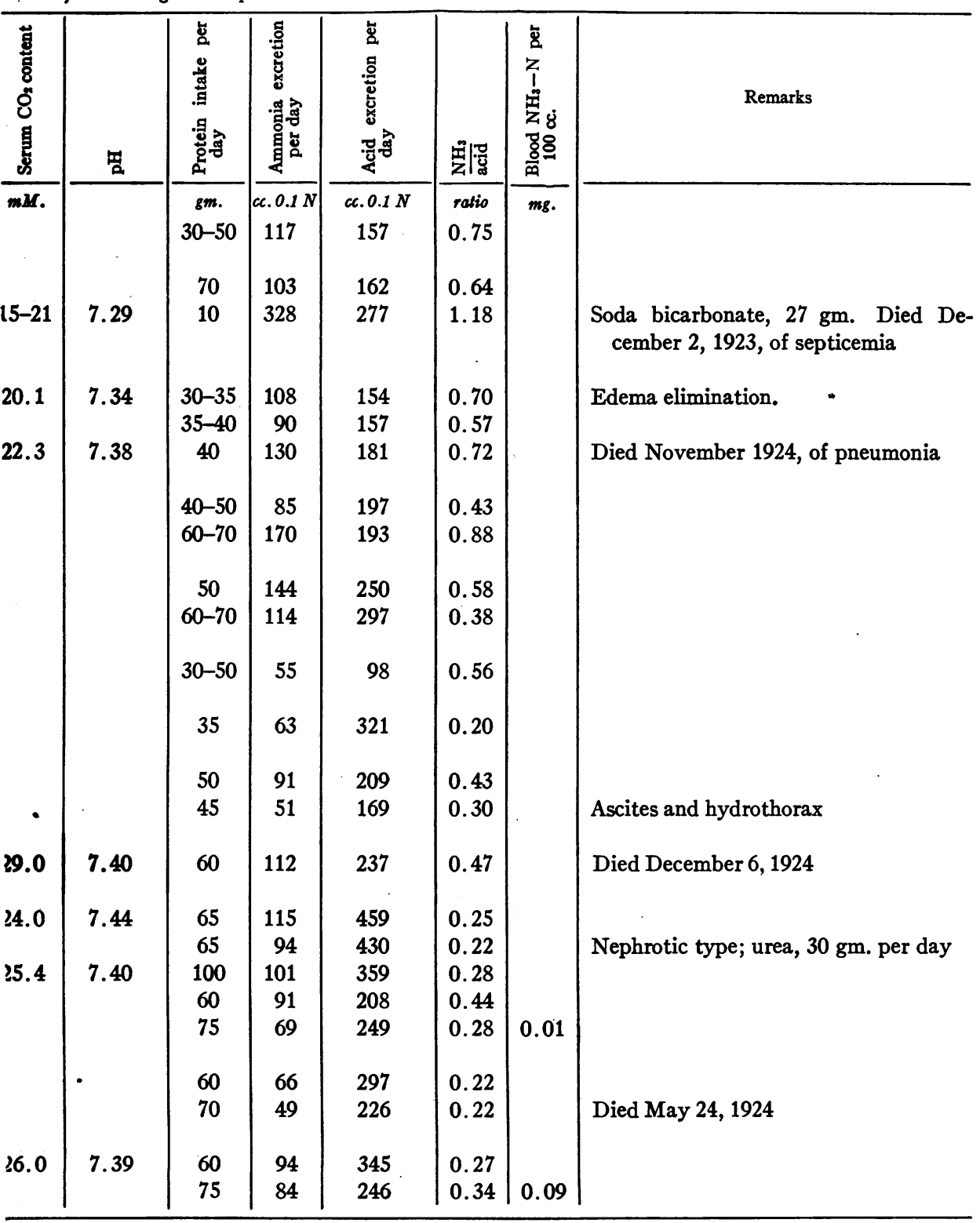


TABLE 8

\begin{tabular}{|c|c|c|c|c|c|c|c|c|}
\hline 息 & छ̋ & 足 & 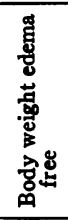 & Period of observation & 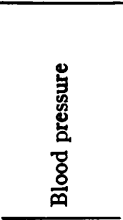 & 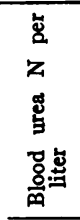 & 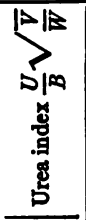 & 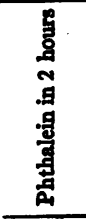 \\
\hline & & years & kg. & 1923 & & $\mathrm{gm}$. & & por cout \\
\hline 44 & S. Ly. & 15 & 40 & $\begin{array}{c}\text { January } 21-\text { February } 18 \\
\text { February 20-February } 22 \\
\text { March 4-March } 27 \\
1924-1925\end{array}$ & $\begin{array}{l}158 / 100 \\
165 / 102\end{array}$ & $\begin{array}{l}0.28 \\
0.17\end{array}$ & $\begin{array}{l}13.6 \\
13.6\end{array}$ & $\begin{array}{l}5 \\
7\end{array}$ \\
\hline 45 & J. L. & 16 & 49 & $\begin{array}{c}\text { October 5-March } 7 \\
\text { May 20-May } 22 \\
1925\end{array}$ & $\begin{array}{l}128 / 68 \\
142 / 80\end{array}$ & $\begin{array}{l}0.20 \\
0.14\end{array}$ & $\begin{array}{l}15.2 \\
34.4\end{array}$ & $\begin{array}{l}69 \\
57\end{array}$ \\
\hline 46 & M. McC. & 20 & 30 & February 19-May 19 & $146 / 90$ & 0.17 & 20.5 & 53 \\
\hline 47 & E. S. & 29 & 49 & $\begin{array}{l}\text { April 27-May } 22 \\
1921-1922\end{array}$ & $200 / 130$ & 0.28 & 9.1 & 16 \\
\hline 48 & M. H. A. & 17 & 50 & $\begin{array}{c}\text { November } 26-\text { January } 10 \\
\text { January } 12-\text { June } 13 \\
1924 \\
\text { June 30-July } 17 \\
1925\end{array}$ & $140 / 80$ & $\begin{array}{l}0.33 \\
0.36 \\
0.40\end{array}$ & $\begin{array}{r}17.8 \\
10.2 \\
4.1\end{array}$ & $\begin{array}{l}51 \\
42\end{array}$ \\
\hline & & 20 & & \begin{tabular}{l} 
January 19-February 17 \\
February 27-March 17 \\
March 22-April 21 \\
April 22-May 12 \\
\multicolumn{1921}{|c|}{}
\end{tabular} & $\begin{array}{l}160 / 130 \\
155 / 130 \\
150 / 130 \\
130 / 100\end{array}$ & $\begin{array}{l}0.92 \\
0.66 \\
0.84 \\
1.14\end{array}$ & $\begin{array}{l}4.5 \\
3.5 \\
1.5 \\
1.3\end{array}$ & Trace \\
\hline 49 & S. L. & 17 & 57 & $\begin{array}{c}\text { November 1-November } 5 \\
\text { November 6-November } 24 \\
\text { November 27-December } 11 \\
1922 \\
\text { February 1-April } 12 \\
1923 \\
\text { December 26-December } 29 \\
1923\end{array}$ & $140 / 70$ & $\begin{array}{l}0.31 \\
0.20 \\
0.12 \\
0.29 \\
0.49\end{array}$ & $\begin{array}{r}23.0 \\
9.6 \\
12.5\end{array}$ & $\begin{array}{l}16 \\
20 \\
31 \\
29 \\
8\end{array}$ \\
\hline 50 & M. F. & 25 & 48 & $\begin{array}{l}\text { January } 7 \text {-January } 21 \\
\text { January } 23-\text { February } 13 \\
\text { February 15-March } 8 \\
\text { March 11-May } 27 \\
1924\end{array}$ & $\begin{array}{l}180 / 130 \\
155 / 105 \\
145 / 95 \\
160 / 110\end{array}$ & $\begin{array}{l}0.78 \\
0.54 \\
0.53 \\
0.55\end{array}$ & $\begin{array}{l}6.2 \\
5.0 \\
5.9 \\
5.1\end{array}$ & $\begin{array}{l}17 \\
20 \\
26\end{array}$ \\
\hline 51 & C. A. & 34 & 50 & $\begin{array}{l}\text { October 13-December } 19 \\
1923\end{array}$ & $180 / 104$ & 0.72 & 5.2 & 5 \\
\hline 52 & E. L. & 33 & 48 & 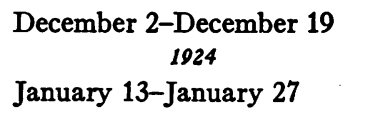 & $220 / 120$ & $\begin{array}{l}0.47 \\
0.37\end{array}$ & $\begin{array}{l}6.3 \\
5.2\end{array}$ & $\begin{array}{l}\text { Trace } \\
\text { Trace }\end{array}$ \\
\hline
\end{tabular}




\begin{tabular}{|c|c|c|c|c|c|c|c|c|}
\hline \multicolumn{9}{|c|}{- Conotromed } \\
\hline 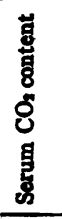 & 罟 & 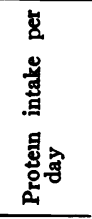 & 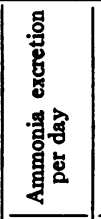 & 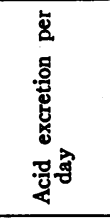 & 帘|: & 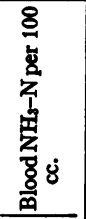 & \multicolumn{2}{|l|}{ Remarks } \\
\hline$m \boldsymbol{~} \boldsymbol{L}$. & & $g m$. & cc. $0.1 \mathrm{~N}$ & $c c .0 .1 \mathrm{~N}$ & $\overline{\text { ratio }}$ & $m g$. & & \\
\hline & & 50 & 36 & 256 & 0.14 & & & \\
\hline & & 50 & 60 & 230 & 0.26 & & $\mathrm{CaCl}_{2}, 12 \mathrm{gm}$. per day & \\
\hline 1.3 & 7.39 & 50 & 46 & 191 & 0.24 & . & & \\
\hline 7.0 & 7.42 & 55 & 62 & 311 & 0.20 & & & \\
\hline & & & 24 & 100 & 0.24 & & & \\
\hline 4.0 & 7.45 & $40-50$ & 61 & 205 & 0.30 & 0.01 & & \\
\hline 5.8 & 7.47 & 50 & 48 & 139 & 0.35 & & & \\
\hline 3.0 & $\cdot$ & $30-60$ & 132 & 321 & 0.41 & & & \\
\hline & & 60 & 90 & 300 & 0.30 & & & \\
\hline & & $20-40$ & 51 & 122 & 0.42 & & & \\
\hline 9.8 & 7.37 & 45 & 44 & 154 & 0.29 & & & \\
\hline & & 45 & 22 & 87 & 0.25 & & & \\
\hline & & & 41 & 112 & 0.37 & 0.06 & & \\
\hline & & & 15 & 51 & 0.29 & & Died May 26, 1925 & \\
\hline 6.2 & 7.22 & 30 & 114 & 270 & 0.42 & & Acidosis; $60 \mathrm{gm} . \mathrm{NaHCO}_{3}$ & \\
\hline & & 35 & 55 & 191 & 0.29 & & & \\
\hline 0.5 & 7.48 & 30 & 107 & 176 & 0.61 & & Edema elimination & \\
\hline & & 50 & 74 & 190 & 0.39 & & & \\
\hline & & 40 & 70 & 340 & 0.22 & & Died June, 1924 & \\
\hline 2.7 & 7.39 & $30-50$ & 69 & 293 & 0.24 & & & \\
\hline & & $40-50$ & 70 & 273 & 0.26 & & Edema elimination & \\
\hline & & $60-70$ & 69 & 235 & 0.29 & & & \\
\hline & & $40-50$ & 53 & 224 & 0.24 & & Died April 20, 1925 & \\
\hline 4.0 & 7.35 & 55 & 58 & 235 & 0.25 & & . & . \\
\hline 1.9 & 7.34 & $30-40$ & 53 & $176^{\circ}$ & 0.30 & & & \\
\hline 6.5 & 7.39 & $40-45$ & 21 & 112 & 0.19 & & Died July, 1924 & \\
\hline
\end{tabular}


TABLE 8

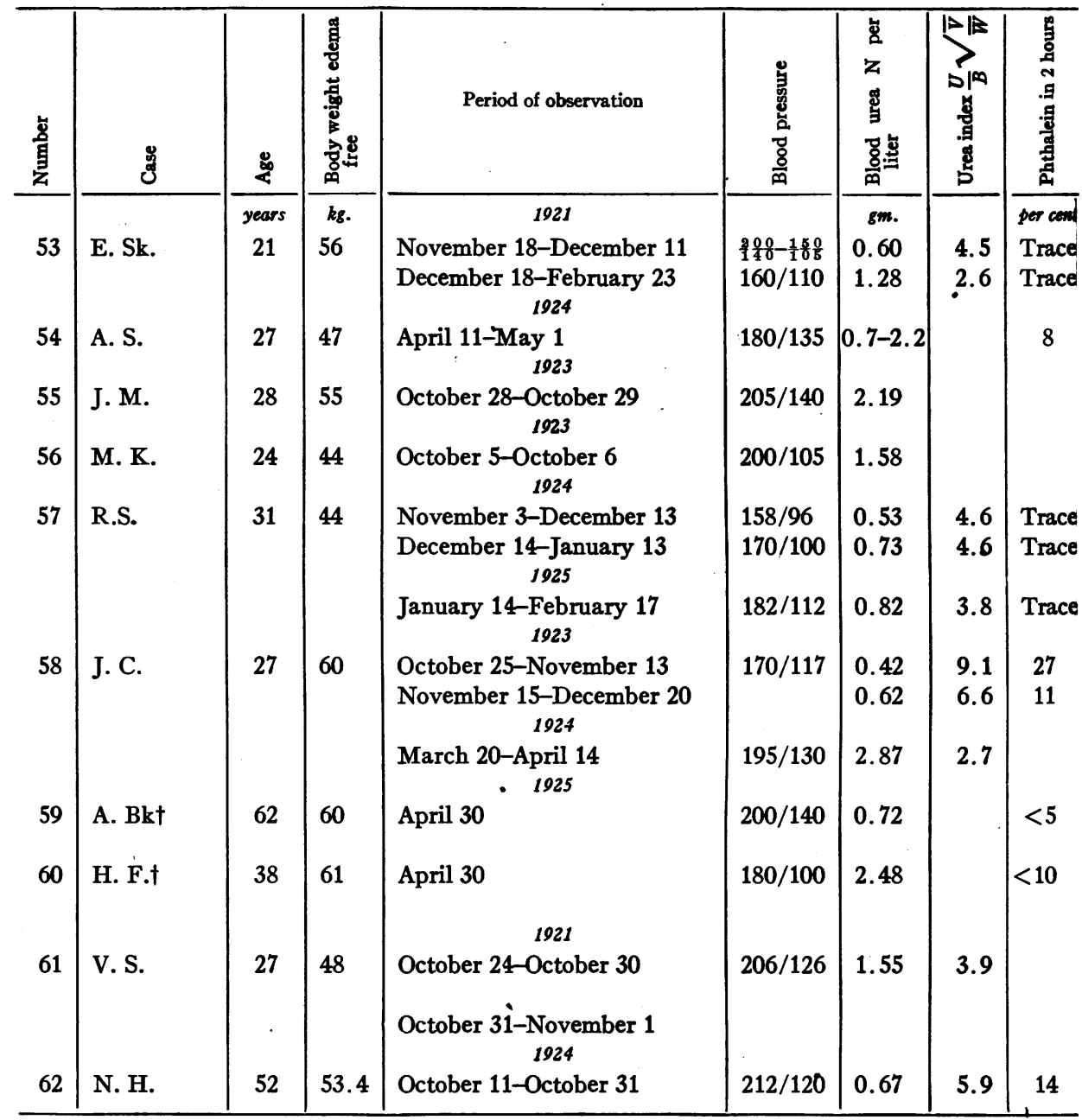

† These cases were obtained from the Presbyterian Hospital through the courtesy of Dr. Atchley.

Autopsies were performed on J. D., M. H. A., S. L., E. L., E. Sk., A. S., J. M., and V. S., and the findings in each case confirmed the clinical diagnosis.

Acid and ammonia excretion in nephritic acidosis. As pointed out above, in normal individuals and in nephrosis the threat of acidosis induced by administration of calcium chloride leads to a somewhat 


\begin{tabular}{|c|c|c|c|c|c|c|c|}
\hline \multicolumn{8}{|c|}{-Concluded } \\
\hline $\begin{array}{l}\text { 苞 } \\
8 \\
8 \\
8 \\
8 \\
\text { 息 } \\
\end{array}$ & 畏 & 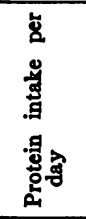 & 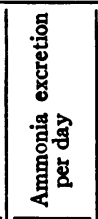 & 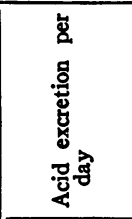 & 公|: & 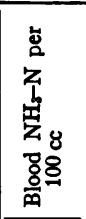 & Remarks \\
\hline$m \boldsymbol{m}$. & & $g m$. & $c .0 .1 \mathrm{~N}$ & $c c .0 .1 \mathrm{~N}$ & ratio & $m g$. & \\
\hline 16.4 & & $10-50$ & 44 & 259 & 0.17 & & \\
\hline 20.5 & & $70-90$ & 57 & 248 & 0.23 & & Died March 17, 1921 \\
\hline $23-13$ & $7.35-7.22$ & $30-2$ & 21 & 70 & 0.30 & & Died May 30, 1924 \\
\hline 18.0 & 7.30 & $6-0$ & 18 & 127 & 0.14 & & Died October 30, 1923 \\
\hline 15.9 & 7.37 & $30-0$ & 9 & 135 & 0.07 & & $\begin{array}{l}\text { Became incontinent. Died October 11, } \\
1923\end{array}$ \\
\hline 23.2 & 7.40 & $\begin{array}{l}55 \\
60\end{array}$ & $\begin{array}{l}19 \\
40\end{array}$ & $\begin{array}{l}162 \\
305\end{array}$ & $\begin{array}{l}0.12 \\
0.13\end{array}$ & & \\
\hline 21.0 & 7.29 & 60 & 21 & 184 & 0.11 & & Died May 12,1925 \\
\hline 22.7 & 7.31 & $\begin{array}{c}50-60 \\
60\end{array}$ & $\begin{array}{l}119 \\
620\end{array}$ & $\begin{array}{c}369 \\
\text { Neutral }\end{array}$ & $\begin{array}{c}0.32 \\
\infty\end{array}$ & & \\
\hline 16.2 & 7.24 & $30-0$ & 349 & 75 & 4.66 & & Died April 15, 1924 \\
\hline 11.7 & & & $\begin{array}{l}748 \\
298\end{array}$ & $\begin{array}{l}\text { Alkaline } \\
\text { Alkaline }\end{array}$ & $\infty$ & $\begin{array}{l}0.01 \\
0.02\end{array}$ & $\begin{array}{l}\text { Uremia, edema; blood creatinine } 4.2 \mathrm{mg} \text {. } \\
\text { in } 100 \mathrm{cc} \text {. } \\
\text { Uremia; blood creatinine, } 26.6 \mathrm{mg} \text {. per } \\
100 \mathrm{cc} \text {. Died May } 21 .\end{array}$ \\
\hline 18.7 & 7.33 & 50 & $\begin{array}{r}11 \\
295\end{array}$ & $\begin{array}{c}82 \\
\text { Alkaline }\end{array}$ & $\begin{array}{r}0.13 \\
\infty\end{array}$ & & $\begin{array}{l}\text { Malignant nephrosclerosis. Uremia; } \\
\text { blood creatinine, } 24.7 \mathrm{mg} \text {. in } 100 \mathrm{cc} \text {. } \\
\text { Died November } 1,1921\end{array}$ \\
\hline & & 55 & 44 & 163 & 0.27 & & Malignant nephrosclerosis \\
\hline
\end{tabular}

greater proportional increase in the excretion of ammonia than in that of acid, so that the ammonia-acid ratio increases. In contrast with this is the reaction of the kidney in chronic nephritis (7). Thus, in S. L., 44, whose ammonia-acid ratio was already low, the administration of calcium chloride led to no significant increase in the ammonia excretion or the ammonia-acid ratio. It is presumable, therefore, 


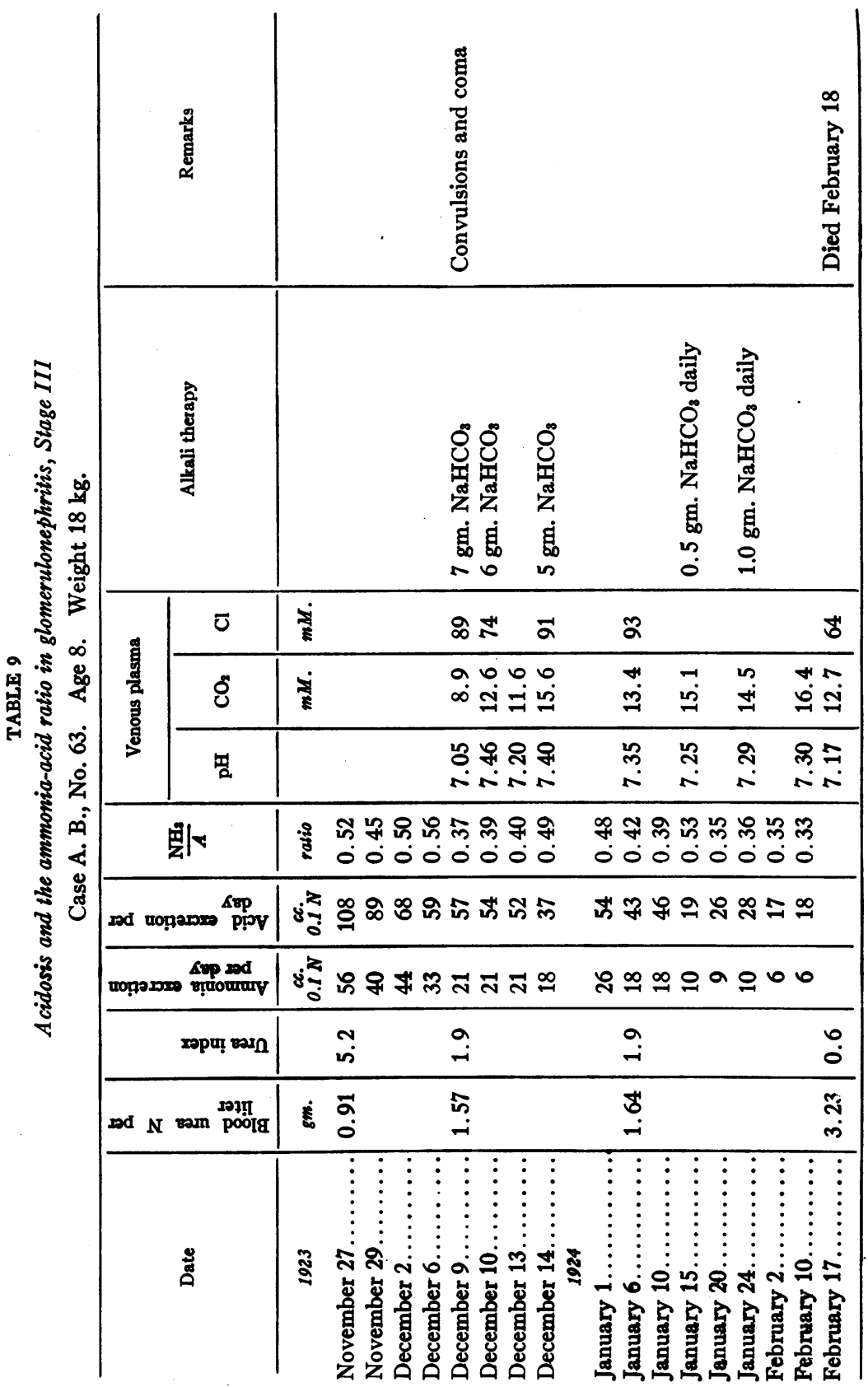


that the acidosis noted in the more severe forms of nephritis (A. S., 54 , and A. B., 63) was due to inability of the organism to form more than small amounts of ammonia.

The spontaneous occurrence of acidosis in a severe form is illustrated in the case of A. B., 63, a boy of 8 , who had had glomerulonephritis for 3 years and who was under observation for the last 3 months of his life (table 9). There was no history of edema and the

TABLE 10

The ammonia content of the blood in normal and nephritic subjects

\begin{tabular}{|c|c|c|c|c|c|c|}
\hline Subject & $\begin{array}{l}\text { Urea } \\
\text { index }\end{array}$ & $\left|\begin{array}{c}\text { Ammonia } \\
\text { excre- } \\
\text { tion per } \\
\text { day }\end{array}\right|$ & $\begin{array}{l}\text { Acid } \\
\text { excretion per } \\
\text { day }\end{array}$ & $\frac{\mathrm{NH}_{3}}{\mathrm{~A}}$ & $\begin{array}{c}\text { Blood } \\
\mathrm{NH}_{\mathrm{p}-\mathrm{N}} \\
100 \mathrm{cc}\end{array}$ & Diagnosis \\
\hline & & $c c .0 .1 \mathrm{~N}$ & $c c .0 .1 \mathrm{~N}$ & ratio & $m g$. & \\
\hline L. L.. & 54.0 & $12.9^{*}$ & $12.4^{*}$ & 1.04 & 0.06 & Normal \\
\hline W. N.. & 44.2 & $23.5^{*}$ & $15.6^{*}$ & 1.51 & 0.10 & Normal \\
\hline G. G... & 34.6 & 218 & 243 & 0.90 & 0 & Nephrosis \\
\hline M. R.. & 28.2 & 134 & 116 & 1.16 & 0.01 & Nephrosis \\
\hline B. F... & 31.5 & 312 & 166 & 1.88 & 0.02 & Nephrosis \\
\hline D. G.... & 73.8 & 232 & 181 & 1.28 & 0.01 & $\begin{array}{l}\text { Glomerulonephritis, } \\
\text { Stage I }\end{array}$ \\
\hline R. N. & 18.6 & 69 & 249 & 0.28 & 0.01 & $\begin{array}{l}\text { Glomerulonephritis, } \\
\text { Stage III }\end{array}$ \\
\hline P. L.. & 21.7 & 84 & 246 & 0.34 & 0.09 & $\begin{array}{l}\text { Glomerulonephritis, } \\
\text { Stage III }\end{array}$ \\
\hline M. McC.... & 20.5 & 61 & 205 & 0.30 & 0.01 & $\begin{array}{l}\text { Glomerulonephritis, } \\
\text { Stage III }\end{array}$ \\
\hline M. H. A... & 1.5 & 41 & 112 & 0.37 & 0.06 & $\begin{array}{l}\text { Glomerulonephritis, } \\
\text { Stage III }\end{array}$ \\
\hline A. Bk.. & & 748 & Alkaline & & 0.01 & $\begin{array}{l}\text { Glomerulonephritis, } \\
\text { Stage III }\end{array}$ \\
\hline H. F & & 298 & Alkaline & & 0.02 & \\
\hline
\end{tabular}

* Excretion per hour.

blood pressure was not raised. There was retention of nitrogen at the time of admission and this rapidly increased. He had convulsions which were associated with extreme uncompensated acidosis; this was partially controlled with bicarbonate and no further convulsions occurred. With this persistent acidosis the excretion of ammonia and titratable acidity was small and steadily diminished. As both were equally affected the ratio did not change. Hence it appears that there is a possibility of only a moderately diminished ammonia-acid ratio 
in severe forms of nephritis when the titratable acid excretion is also impaired, and acidosis develops. On the other hand, in spite of the low ammonia excretion, if the titratable acid remains at about the normal level, acidosis may be, and frequently is, absent.

Caution appears necessary in the use of calcium chloride, ammonium chloride, or any other acid forming diuretic, in the attempt to eliminate edema in patients with low ammonia-acid ratios, or with advanced glomerulonephritis. The kidneys may be unable to respond to the extra strain on the acid excreting mechanism, and acid intoxication may develop. It is desirable to follow the $\mathrm{pH}$ and bicarbonate of the serum closely during the use of such diuretics.

The ammonia of the blood. Table 10 shows values for blood ammonia nitrogen in normal subjects and in different types of nephritis, including terminal uremia. The highest figure, $0.10 \mathrm{mg}$. per $100 \mathrm{cc}$., occurred in a normal subject, and the lowest figures, 0 to 0.01 , occurred in individuals with various forms of nephritis. Similar results have been reported by Rabinowitch (26) and Russell (28), who used the Nash and Benedict technique (21). In spite of the fact that there was a markedly diminished ammonia excretion in some of the cases, the blood ammonia showed no increase. These observations indicate that no retention of ammonia occurs comparable to that of other nitrogenous constituents. The diminished ammonia output is due not to retention but to diminished formation.

\section{SUMMARY}

In those forms of nephritis (nephrosis and benign nephrosclerosis) in which the urea excreting function is quantitatively unimpaired, both ammonia and titratable acid have been found to be excreted in normal amount and proportion. The usual ammonia-acid ratios in the urine in such cases exceed 1.

In acute glomerulonephritis a tendency to low ammonia-acid ratios was present in some cases, absent in others.

In those forms of nephritis with quantitatively impaired urea concentrating function (chronic glomerulonephritis and some cases of acute glomerulonephritis) there was regularly a low ammonia-acid ratio of 0.7 to 0.1 in the urine. It was due, as found by Henderson and Palmer, 
to diminished ammonia output. The titratable acidity was relatively well maintained until the final stage of complete renal insufficiency.

The drop in the ammonia-acid ratio, was not always proportional to the fall in urea excreting power nor to the severity of the clinical condition. Cases with clinically mild chronic nephritis and urea concentration indices of 20 to 30 (instead of the usual normal above 40) may show ammonia-acid ratios as low (0.2 to 0.3$)$ as other cases approaching uremia and with concentration indices below 5. A possible explanation of the failure of the ammonia-acid ratio to be proportionally depressed in cases with very low urea function is that in them the ability to excrete titratable acid as well as ammonia is reduced.

The ammonia content of the blood was as low or lower in those forms of nephritis with diminished ammonia output as in normal individuals. The fall in ammonia excretion in glomerulonephritis appears, therefore, due not to ammonia retention in the body, but to failure to form ammonia in proportions normally related to those of the acid metabolites. The concurrence of diminished ammonia formation with diminished kidney function is compatible with the conclusion of Nash and Benedict, that ammonia is formed in the kidney.

The determination of the ammonia-acid ratio in the urine is technically simple, and consistently normal values of the ratio in repeated determinations appear to exclude the possibility of serious renal impairment. The fall in the ratio, however, although present in all cases thus far observed with impaired urea concentrating power, does not regularly parallel the fall in the urea concentrating or excreting power. The decrease in urea function is more closely correlated with the clinical severity of the nephritis.

\section{BIBLIOGRAPHY}

1. Austin, J. H., Stillman, E., and Van Slyke, D. D.: Jour. Biol. Chem., 1921, xlvi, 91.

2. Barnett, G. D.: Jour. Biol. Chem., 1917, xxix, 459.

3. Blum, L., Aubel, E., and Hausknecht, R.: Bull. et mém. Soc. med. d. hôp. de Paris, 1921, xlv, 1561, and 1922, xlvi, 206.

4. Fitz, R., and Van Slyke, D. D.: Jour. Biol. Chem., 1917, xxx, 389.

5. Folin, O., and Denis, W.: Jour. Biol. Chem., 1912, xi, 161 and 527.

6. Folin, O.: Amer. Jour. Physiol., 1903, ix, 265.

7. Gamble, J. L., Blackfan, K. D., and Hamilton, B.: Jour. Clin. Invest., 1925, i, 359. 
8. Gherardini, S.: Arch. di scienze biol., 1923, iv, 213.

9. Hahn, A., and Kootz, E.: Biochem. Zeitsch., 1920, cv, 220.

10. Hastings, A. B., and Sendroy, J., Jr.: Jour. Biol. Chem., 1924, lxi, 695.

11. Henderson, L. J.: Jour. Biol. Chem., 1911, ix, 403.

12. Henderson, L. J., and Palmer, W. W.: Jour. Biol. Chem., 1915, xxi, 37.

13. Henderson, L. J., and Palmer, W. W.: Jour. Biol. Chem., 1914, xvii, 305.

14. Hiller, A., Linder, G. C., Lundsgaard, C., and Van Slyke, D. D.: Jour. Exp. Med., 1924, xxxix, 931.

15. Linder, G. C., Lundsgaard, C., and Van Slyke, D. D.: Jour. Exp. Med., 1924, xxxix, 887.

16. Linder, G. C., Lundsgaard, C., Van Slyke, D. D., and Stillman, E.: Jour. Exp. Med., 1924, xxxix, 921.

17. Linder, G. C., Hiller, A., and Van Slyke, D. D.: Jour. Clin. Invest., 1925, i, 247.

18. Loeb, R. F., Atchley, D. W., and Benedict, E. M.: Jour. Biol. Chem., 1924, $\mathrm{lx}, 491$.

19. Marriott, W. M., and Howland, J.: Arch. Int. Med., 1918, xxii, 477.

20. McIntosh, J. F., Leiter, L., Stillman, E., and Van Slyke, D. D.: To be published.

21. Nash, T. P., and Benedict, S. R.: Jour. Biol. Chem., 1921, xlviii, 463.

22. Oberfell, G. G., and Mase, R. P.: Jour. Ind. and Eng. Chem., 1919, xi, 294.

23. Parnas, J. K., and Heller, J.: Biochem. Zeitsch., 1924, clii, 1.

24. Parnas, J. K.: Biochem. Zeitsch., 1925, clv, 247.

25. Rabinowitch, I. M.: Arch. Int. Med., 1924, xxxiii, 394.

26. Rabinowitch, I. M.: Can. Med. Assoc. Jour., 1923, xiii, 742.

27. Rowntree, L. G., and Geraghty, J. T.: Arch. Int. Med., 1912, ix, 284.

28. Russell, D. S.: Biochem. Jour., 1923, xvii, 72.

29. Salvesen, H. A., Hastings, A. B., and McIntosh, J. F.: Jour. Biol. Chem., 1924, lx, 327.

30. Sherman, H. C., and Gettler, A. O.: Jour. Biol. Chem., 1912, xi, 323.

31. Stillman, E., Van Slyke, D. D., Cullen, G. E., and Fitz, R.: Jour. Biol. Chem., 1917, xxx, 405.

32. Strauss, H.: Zentr. f. inn. Med., 1922, xliii, 26.

33. Van Slyke, D. D., and Cullen, G. E.: Jour. Biol. Chem., 1914, xix, 211; 1916, xxiv, 117.

34. Van Slyke, D. D., and Neill, J. M.: Jour. Biol. Chem., 1924, lxi, 523.

35. Volhard, F., and Fahr, T.: Die Brightsche Nierenkrankheit. Berlin, 1914.

36. Volhard, F.: Die doppelseitigen hämatogenen Nierenkrankungen. Berlin, 1918. 